\title{
ENTRE VALENCIA Y BARCELONA: SOBRE LOS CAMINOS DE LA PINTURA, GUERAU GENER Y LOS TIEMPOS DEL GÓTICO INTERNACIONAL.
}

\section{ROSA ALCOY}

UDC: $75 \cdot 033 \cdot 5(460.235+460.313)$

R. Alcoy

Original scientific paper

Manuscript received: 20. 11. 2015.

Revised manuscript accepted: 16. 03. 2016.

DOI: 10.1484/J.HAM.5.111356

Universitat de Barcelona

Barcelona, Spain

rosaalcoypedros@gmail.com

The importance of International Gothic in the ports of the Catalano-Aragonese crown is a fact that coincides with the transcendence of the style throughout the Kingdom. Valencia and Barcelona stand out as the most powerful centers, bringing together innovative, subtle, refined painters arriving from different parts of Europe. Among those Guerau Gener may not be the most well-known, but is certainly the most clearly linked to workshops active in both capitals at the same time. This Master would move from one capital to the other, altering the creative rhythms that made up his style to the beat of the new figurative dreams of the Gothic art of 1400. In this paper I wish to address these specific currents that, emanating from both capitals, imbue the scarce yet coherent work of Guerau Gener. His work imbibed of diverse models that were all of great quality, though of different origins. Its production by no means be confined within the boundaries of a local market. On the contrary, his painting received attention in various Mediterranean centers, to which the painter perhaps could not reach as widely and timely as would have been predicted, due to an early death that disrupted a meritorious career in 1410.

Keywords: Guerau Gener, international Gothic, Barcelona, Valencia, altarpiece

Nadie cuestiona la importancia del gótico internacional en Barcelona y Valencia, reconocidas como los mayores centros portuarios de la Corona catalano-aragonesa en aquellos tiempos. ${ }^{1}$ Por tanto, no será preciso defender esta idea, que introduzco por ser un cómodo punto de arranque, al inicio de un estudio que versa sobre algunas de las relaciones que se establecieron entre la pintura de ambos escenarios. ${ }^{2}$ Un valor distinto, que no contradice la primera afirmación, debe conferirse al relevante protagonismo de ambas ciudades costeras en la consolidación y la difusión del estilo internacional en el marco peninsular, ${ }^{3}$ con el fin de contemplar su penetración en el resto del territorio y proceder al análisis de las relaciones interurbanas y portuarias que puedan resultar más significativas para el arte y la pintura del momento. ${ }^{4}$ Aunque los planteamientos sobre la situación de la economía de estas ciudades, o en la Corona en su conjunto, pudiera abastecer ciertas sombras, o dudas, con carácter histórico, ${ }^{5}$ lo cierto es que sus centros principales van a proveerse de lo más precioso en el terreno artístico, en una etapa rica en cambios y que nos seduce por sus perfiles positivos, poco controvertidos en este ámbito. ${ }^{6}$
El mismo esfuerzo realizado para obtener éxito, el deseo de destacar, nos descubre factores que redundaron en la calidad de lo realizado, o pudieron contribuir a dar importancia a estos centros, al alimentarla en determinados aspectos. En torno al 1400, tanto Barcelona como Valencia, atraen, e incluso acaparan, a una serie de maestros de primer orden, que actúan como exponentes aventajados del que fue el desarrollo de la mejor pintura del período en el contexto hispánico. De hecho se llega a alcanzar un buen nivel medio, comparable al de lo realizado en algunos de los enclaves europeos que tuvieron mayor peso para el desarrollo del gótico internacional.

La hegemonía de estas capitales en el terreno pictórico se centra en la producción de retablos de modo que, el alto nivel alcanzado, es también un espejo fiel de la tradición y de la trascendencia que obtuvo el gótico en este campo y en el conjunto de los reinos de la Corona.

Durante el siglo XIV, Barcelona se había convertido ya en una gran capital del retablo pintado. Esta preeminencia sobre otros enclaves, llegado el 1400, se va a ver alterada por la pujanza creciente de nuevos centros productivos. ${ }^{7}$ Sin

\footnotetext{
${ }^{1}$ Este estudio ha sido realizado con soporte del proyecto HAR2012-36307 (Estudios sobre el Arte Catalán desplazado. Del contexto Medieval a la interpretación Postmedieval) del Grupo de investigación consolidado EMAC. Románico y Gótico, de la Universidad de Barcelona, financiado por el Ministerio de Economía y Competitividad (2013-2015).

${ }^{2}$ Aunque no siempre se valoran unas buenas expectativas a medio plazo: A. DÍAZ BORRAS, El ocaso cuatrocentista de Valencia en el tumultuoso mediterráneo, CSIC, 2002.

${ }^{3}$ M. T. FERRER MALLOL, "Navegació, ports i comerç a la mediterrània de la Baixa Edat Mitjana”, José PÉREZ BALLESTER y Guillermo PASCUAL (eds), Actas V Jornadas Internacionales de Arqueología Subacuática, (Gandía, 8 a 10 de noviembre de 2006), Valencia, 2007, pp. 113-166

${ }^{4}$ Sobre las vías de comunicación en la Corona: A. RIERA I MELIS, “La red viaria de la Corona Catalanoaragonesa en la Baja Edad Media”, Acta Mediaevalia, n. 23-24, 2002, p. 441-467.

${ }_{5}^{5}$ C. CARRÈRE, Barcelona 1380-1462. Un centre econòmic en época de crisi, 2 vols., ed. Curial, Barcelona, 1977; E. BELNGUER CEBRIÀ, València en la crisi del segle $X V$, edicions 62, Barcelona, 1976.

${ }^{6}$ A. DÍAZ BORRÁS, El ocaso cuatrocentista de Valencia en el tumultuoso mediterráneo, 1400-1480, Barcelona, CSIC, 2002. E. CRUSELLES GÓMEZ, "El Puerto de Valencia en el Mediterráneo medieval (siglos XIII-XV)", J. HERMOSILLA PLA (ed.), Historia del Puerto de Valencia, Universitat de Valencia, 2008, pp. 63-125.

${ }^{7}$ R. ALCOY. "Talleres y dinámicas de la pintura del gótico internacional en Cataluña”, M. del C. LACARRA DUCAY (ed.), La pintura gótica durante el siglo XV en tierras de Aragón y en otros territorios peninsulares, curso de la cátedra Goya, Institución "Fernando el Católico"(CSIC), Zaragoza, 2007, p. 139-205 y especialmente: R. ALCOY (coord.), Pintura I. De l'inici a l'italianisme, (L’Art Gòtic a Catalunya), Barcelona, 2005.
} 
embargo, quede claro que, el prestigio de estas ciudades, sea para el caso barcelonés o el valenciano, no está reñido con el impulso de talleres notorios en otras sedes cercanas. Al contrario, creo que la existencia de esos talleres alternativos, a modo de afluentes, avala el peso de ambas en materia pictórica y contribuye poderosamente a explicar su fortaleza. ${ }^{8}$ En definitiva, es justo subrayar la proliferación de escuelas y talleres en este período en el marco que ahora nos interesa. ${ }^{9}$ En ellos, un número creciente y revelador de artífices, favoreció la ramificación y florecimiento de las artes relacionadas con la pintura, en centros grandes, medianos o menores, en que se alcanzarían resultados de calidad y originalidades probadas. ${ }^{10}$

Con todos los matices que hacen al caso, Valencia y Barcelona, destacan por ser los focos peninsulares más llamativos del gótico internacional, tanto si nos referimos a la producción localizada como si se trata de hablar de la recepción de piezas llegadas de otros lugares, también importantes para la consolidación del estilo. Al mismo tiempo hay que tener en cuenta que ambas ciudades se postulan como introductoras de las nuevas modalidades del gótico, ya bien encajadas en sus espacios más reveladores y prestigiosos algo antes de que concluya el siglo XIV." No deben menospreciarse los obradores activos en las ciudades que tuvieron puerto directo, como Tarragona, con apoyos en Cambrils i Salou, o el peculiar caso de Tortosa. Tampoco algunos de los principales enclaves portuarios insulares - Palma de Mallorca (Ciutat) o Mahón o los puertos sardos y sicilianos - ${ }^{12}$ si nos limitamos a los centros urbanos costeros o a la vía marítima abierta por el Delta del Ebro y que permitía acceder en embarcación a Tortosa, enclave de interior. ${ }^{13}$ Es bastante evidente, con todo, que en otros muchos casos, no en todos, la incidencia de las novedades se define a la sombra, o al abrigo, según se mire, de lo que sucede en las ciudades aludidas. Si bien es justo considerar la personalidad y perfil específicos de cada espacio creativo, los intercambios no dejaron de fluir en este magnífico momento, acentuando las orientaciones figurativas de la nueva época y señalando a sus más destacados protagonistas. Recordemos que otros centros importantes para la corona catalano-aragonesa, que generaron escuelas específicas del gótico internacional, también tenían sus salidas al mar. Perpiñán la tenía por Colliure y Gerona por Sant Feliu de Guíxols. ${ }^{14}$ Las celebradas conexiones con los núcleos valencianos y barceloneses del arte pictórico que aterriza en territorio aragonés, no dejan de ser un aspecto a tener

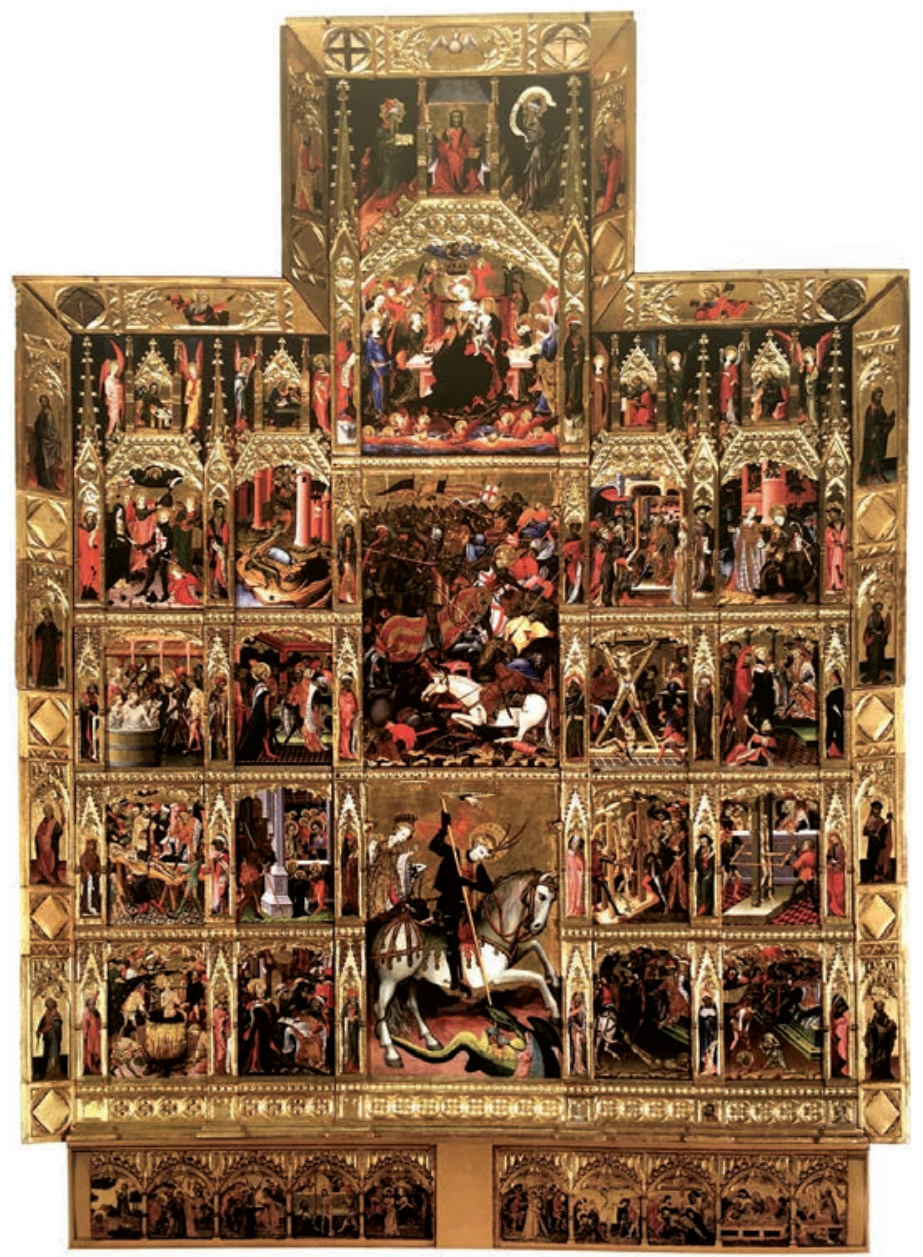

Fig. 1. Marçal de Sas y colaboradores, Retablo de Centenar de la Ploma, Victoria and Albert Museum, Londres

muy en cuenta, sin menosprecio alguno por la interesante aportación del reino de Aragón a las artes del gótico internacional. No olvidemos que Aragón había proporcionado a estas ciudades costeras artistas notorios, como Llorenç Saragossa o Pere de Valldebriga.

Por razones que pueden ser algo distintas para cada caso, tanto Valencia como Barcelona fueron capaces de congregar figuras innovadoras, sutiles, refinadas y también, y lógicamente, heterogéneas. La diversidad puede relacionarse con el hecho de que algunos pintores llegaran de distintas zonas de Europa ${ }^{15}$ pero también con la proliferación de distintos

\footnotetext{
${ }^{8}$ R. ALCOY. “Talleres y dinámicas de la pintura...”, p. 139-205y el libro coordinado por F. RUIZ I QUESADA, Pintura II. El gòtic internacional, Barcelona, 2005. 9 Para observar los entramados más prácticos vinculados al mundo del retablo en el caso valenciano: A. SERRA DESFILIS y M. MIQUEL JUAN. "La madera del retablo y sus maestros. Talla y soporte en los retablos medievales valencianos", Archivo de Arte Valenciano, 2010, p.13-38; M. MIQUEL JUAN, Retablos, prestigio y dinero. Talleres y mercado de pintura en la Valencia del gótico internacional, ed. Universitat de València, València, 2008.

${ }^{10}$ Dejo de lado la miniatura, no sin advertir su interés específico para circulación de determinados modelos y las intersecciones lógicas con otros campos pictóricos. Para Valencia puede verse la reciente aportación de N. RAMON MARQUÉS, La iluminación de manuscritos en la Valencia gótica (1290-1458), Generalitat Valencia, València, 2007.

"Como ya he advertido en otras ocasiones, no es muy productivo intentar establecer prioridades técnicas en la introducción del gótico internacional en el campo de la pintura. A mi entender hay que abordar el problema integralmente, sin prescindir de ninguno de los prismas creativos en acción, pero teniendo en cuenta la especificidad de cada uno de sus registros y sus previsibles interacciones.

${ }^{12}$ La pintura del gótico internacional en Sicilia ha sido abordada en distintas ocasiones por L. Buttà, véase: L. BUTTÀ, La pittura tardogotica in Sicilia. Incontri mediterranei, Palermo, 2008. Para el caso sardo: R. SERRA, Storia dell'arte in Sardegna. Pittura e scultura dall'età romanica alla fine del'50o, Ilisso Edizioni, (Storia dell'arte in Sardegna. Collana diretta da Corrado Maltese) (aparato de notas y fichas a cargo de R. Coroneo), Nuoro, 1990.

${ }_{13}$ Una memòria concreta. Pere Lembrí. Pintura de Morella y Tortosa (1399-1421), Castelló, 2004; La luz de las imágenes, Tortosa-Sant Mateu, Castelló, 2005, R. ALCOY, "Aproximació a la pintura gòtica", Història de les Terres de l'Ebre. Art i cultura, Tortosa, 2010, pp.85-95

${ }^{14}$ F. MARTÍNEZ ABELLA, El port de sant Feliu de Guíxols, Barcelona, 1991. S. ORVIETANI BUSCH, Medieval Mediterranean Ports: The Catalan and Tuscan Coasts, 1100-1235, Leiden, 2001, pp.80-90.
} 


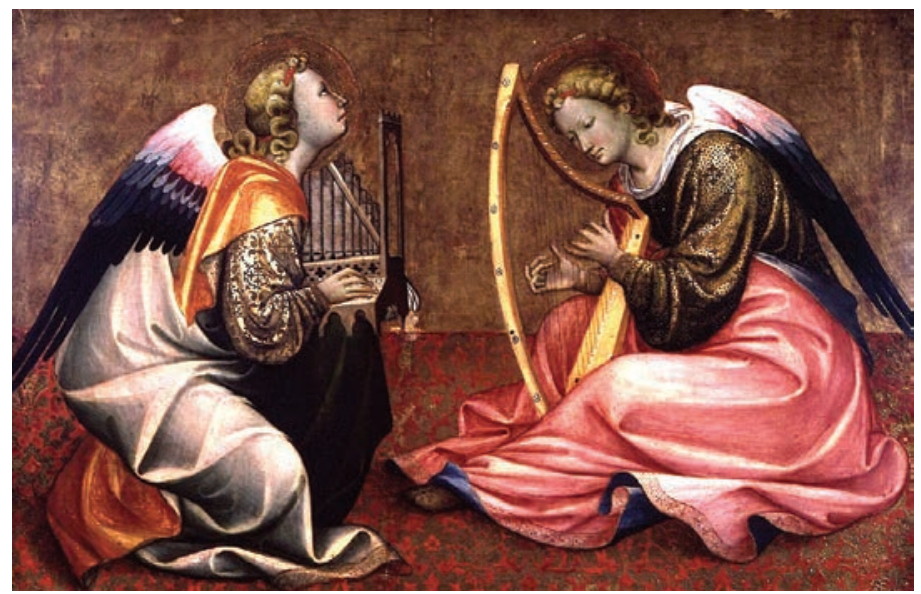

Fig. 2. Gherardo Starnina, Ángeles músicos. Museo Boijmans van Beuningen, Rotterdam

estilos personales de calidad, que imponen y establecen sus formas más características, con una convicción que no está reñida ni con las colaboraciones en empresas comunes ni con la admiración y aprensión, en ese mismo juego, de los modelos de otros maestros.

El arribo de extranjeros permite presentir la introducción de novedades que repercutieron en el ambiente, con planteamientos, obras y estilos varios, asociados a las culturas de origen. Está claro que maestros como Marçal de Sas o Gherardo Starnina enriquecieron el horizonte peninsular pero su venida, acredita también, y en mucho, la capacidad de convocatoria de la ciudad de acogida [figs.1-2]. Lo que sucede en otras partes del territorio no puede ser visto al margen de este proceso, rico en intercambios, ajustes y adaptaciones consecutivas, asociadas a la dinámica artística brillante de estas urbes portuarias, receptivas de las invenciones más atractivas de su tiempo.

Barcelona partía de una industriosa tradición, incuestionable en el campo del retablo, una práctica establecida por talleres que habían servido obras a tierras peninsulares e insulares de toda la Corona. ${ }^{16}$ Estos usos, ya promovidos por el taller de los Bassa y estabilizados, sobre unas bases italianas, sólidas y bien reconocibles, enraizaron con fuerza a lo largo del segundo cuarto del siglo XIV para mantenerse, bastante estables, a lo largo de la segunda mitad del Trecento. Además de Ferrer Bassa y su más que notorio círculo, enlazado también con el mundo aviñonés, ${ }^{17}$ se cuentan, a partir del 1350, pintores como Ramon Destorrents, Francesc, Pere y Jaume Serra, Llorenç Saragossa, o Saragoçà, o Pere de Valldebriga, que habrían avanzado en sus aportaciones después de la gran epidemia de mediados de siglo, contribuyendo a la trasformación de una escuela barcelonesa, aderezada por frecuencias y estilos diversos, pero siempre dentro de una notoria cohesión, que puso las bases de su fortaleza en los siglos del gótico. La hegemonía que llegaron a adquirir los hermanos Serra, receptores de muchos de los encargos principales del mercado religioso catalán, favorecería la coherencia visible en esta etapa, aunque ni puedan ni deban acallarse algunos discursos paralelos, que despejan esquemas figurativos singulares.

Se advierte también en este período una interesante tendencia a la especialización de los iluminadores que se desvinculan en gran parte de los maestros de la pintura sobre tabla, estableciéndose una diferenciación que, paso a paso, da lugar a campos de trabajo separados con mayor claridad que en las etapas precedentes. ${ }^{18}$ La llegada a Barcelona de Lluís Borrassà, en los años ochenta del siglo XIV, y la presencia de una nueva generación de pintores formados en los talleres italianizantes trecentistas, entre los que sobresalen pintores como Joan Mates o Jaume Cabrera, ${ }^{19}$ secundan las posibilidades de un centro en que se reunieron también, iniciada la última década del Trecento, algunos maestros foráneos, como el maestro de vidrieras Nicolau de Maraya, innovador y verdadero cabeza de escuela en su campo. ${ }^{20}$

Valencia, con una tradición pictórica trecentista también interesante, pero a menudo dependiente de centros catalanes, italianos e insulares, ${ }^{21}$ replanteará por completo su rol en el escenario 1400. Las rutas comerciales de los valencianos, y también de los catalanes, a menudo especializados en el negocio pañero, parecen reseguir las redes de intercambio establecidas por las compañías italianas, pero lo más relevante es constatar que, inmiscuidos en estas dinámicas, se interviene en las grandes rutas del comercio internacional europeo. ${ }^{22}$ En contexto valenciano, Francesc Serra II, Llorenç Saragossa o Esteve Rovira de Chipre, entre otros maestros documentados, habrían dejado ya su huella. ${ }^{23}$ Esta base, ya de por sí atrayente, aunque sea difícil de acotar a la menuda y todavía resulte polémica cuando se trata de resolver las autorías de algunas obras fundamentales, se ensancha en las últimas décadas del XIV y va a beneficiar el empuje de la nueva escuela, aunque lo haga a veces desde un segundo

${ }^{15}$ J. L. HERNANDO, "Los artistas llegados al foco barcelonés durante el gótico internacional (1390-1450). Aspectos documentales", Lambard, vol. VI (19911993), 1994, pp. 359-388.

${ }^{16}$ R. ALCOY (coord.), Pintura I...

${ }^{17}$ R. ALCOY, "Avignone e la Catalogna dei Bassa", Images and Words in Exile Avignon and Italy in the first half of the14th century (1310 -1352), Firenze, 2015.

${ }^{18}$ Apuntamos algunas consideraciones sobre este tema en R. ALCOY (coord.), Pintura I.... Siempre podrán aislarse algunas excepciones, pero la dinámica general llevará a una situación distinta de la imperante en Cataluña antes de la Peste Negra (1348-1350).

${ }^{19}$ R. ALCOY I M. MIRET. Joan Mates, pintor del gòtic internacional, Editorial Ausa, Sabadell 1998; R. ALCOY, "Joan Mates i el retaule de sant Jaume de Vallespinosa”, F. ANGLÈS I J. FUGUET (ed.), Vallespinosa i el seu patrimoni monumental i artístic (segles XII-XVIII), Diputació de Tarragona, Publicacions, Tarragona, 2002, p.113-148. E. PUSCEDDU, "Viaggi mediterranei della pittura: Aspetti e caratteristiche del gotico internazionale in Sardegna", R. Alcoy (ed.), Contextos 1200 i 1400, Barcelona, 2012, pp.107-130.

${ }^{20}$ R. ALCOY, “L'evolució estilística del vitrall medieval a Catalunya” (et alt.), Corpus Vitrearum Medii Aevi, Institut d'Estudis Catalans, Barcelona, 2014, vol. V-1, pp. 287-332.

${ }^{21}$ S. LLONCH PAUSAS, S.: Pintura italogótica valenciana, Anales y Boletín de los Museos de Arte de Barcelona, vol. XVIII, l967-8. (1973).

${ }^{22}$ E. CRUSELLES GÓMEZ, “Jerarquización y especialización de los circuitos mercantiles valencianos (finales del XIV-primera mitad del XV)”, Anales de la Universidad de Alicante, n.7, 1988-1989, pp. 83-109

${ }^{23}$ Puede apreciarse el proceso a partir de los numerosos registros disponibles, recopilados y sistematizados en el útil trabajo realizado por X. COMPANY, J. ALIAGA, L. TOLOSA i M. FRAMIS, Documents de la pintura valenciana medieval i moderna, vol. I (1238-1400), Universitat de València, fonts històriques valencianes, 2005 . 
plano. El gótico internacional valenciano despega bajo los signos característicos del primer momento del estilo, dando entrada en estos escenarios a un nutrido grupo de pintores lúcidos y, sin duda, sensibles exploradores de su oficio.

En abril de 1388, Esteve Rovira de Chipre, pintor vecino de Valencia, fue requerido para trasladarse a Toledo, donde debía pintar un retablo, encargado el año anterior por el obispo Pedro Tenorio (1377-1399), y por el que ya había recibido estipendio. ${ }^{24}$ Se trataba de una obra de gran envergadura, que ha sido muy discutida. Se subraya, en primer lugar, una ambición que parece fuera de lo común, y que ya se advierte en el extenso documento publicado por Almarche en 1920. ${ }^{25}$ El encargo es demostrativo de la importancia de un pintor, Esteve Rovira, todavía no identificado de modo indiscutible. ${ }^{26}$ Tampoco existe certeza sobre el avance de sus trabajos en el retablo toledano y, algunos autores, han dudado de que la obra llegara a buen término e, incluso, que pudiera tenerse por realizada en medida alguna, proponiendo a Starnina como autor alternativo para un conjunto al que, hipotéticamente, pertenecerían las tablas del retablo de la capilla de san Eugenio (catedral de Toledo). ${ }^{27}$

No procede discutir ahora estas apasionantes derivaciones, pero nos ayudan a entender que el poderío asumido por la pintura en el contexto valenciano del 1400 no es fácil de cuestionary tiene uno de sus fundamentos en la vitalidad de la ciudad, que despunta ahora en el contexto de la Corona catalano-aragonesa. ${ }^{28}$ Es posible que los avances y fuerza progresiva del centro fueran causados en buena medida por la necesidad de establecer un equilibrio territorial que garantizase los apoyos necesarios en el marco geográfico meridional de la Corona. La situación de Valencia se antoja ideal mientras que, Alicante, ${ }^{29}$ comparece como un centro más desprotegido o demasiado cercano a las fronteras. ${ }^{30}$ Sea como sea, el balance histórico concreto que configura la renovación de la capital, es un tema de fondo revelador, que va a incentivar la llegada y la integración de esas distintas personalidades que, de modo casi mágico, interactuaron en el campo artístico, configurando la que considero llegó a ser una verdadera escuela pictórica valenciana que no queda fuera del nuevo trazado del gótico, guarnecido por una templada vocación internacional de evidente alcance europeo. Quizás sea este desear estar a la page el otro gran eje a considerar, enmarcado por lo cultural, como fruto fehaciente de una fortuna buscada.

\section{EL CONTEXTO VALENCIANO (1390-1400)}

Pere Nicolau, originario de Cataluña, es una de las personalidades más notables y problemáticas que se dieron cita en la Valencia del primer internacional. Aunque se ha sugerido un paso previo por Barcelona, anterior a su migración a Valencia, el núcleo familiar de Nicolau se relaciona en lo fundamental con la ciudad de Igualada, en la comarca de la Anoia, y con Sant Martí Sarroca, en el Alto Penedés. En esta última localidad habitaba su hermana Gueralda Nicolau, madre de su sobrino, el también pintor Jaume Mateu, que se convertiría en su discípulo y heredero. ${ }^{31}$ En junio de 1390, Pere Nicolau estaba ya en Valencia. ${ }^{22}$ Durante esta década trabajará para la catedral y para el convento de santo Domingo $^{33}$ atendiendo a encargos sobresalientes, que se alargan en la primera década del siglo XV.

La suma de lo que sabemos sobre Nicolau lo convierte en una figura imprescindible en el panorama valenciano de en torno al año 1400 , pese a que las obras que se le han reconocido no satisfacen por completo las expectativas creadas por su capacidad de producción y trayectoria. El retablo de Sarrión (Teruel), hoy en el Museo de Bellas Artes de Valencia [fig.3], documentado para el pintor en 1404, ha sido el eje principal para la reconstrucción de su catálogo y base casi única, por tanto, de otras atribuciones, pese a que, como es

${ }^{24}$ Pedro Tenorio es un personaje de biografía atractiva, en la que merece la pena explorar. Aliado de los Trastámara, viajero y conocedor de Italia y Francia, ha sido relacionado con la construcción, a finales del siglo XIV, de la capilla de san Blas en la catedral de Toledo, obra compleja asociada a su enterramiento. La capilla es bien conocida por el complejo conjunto de murales italianizantes que la decora. Un paralelo funerario interesante nos lo ofrece el Baptisterio de Padova, decorado por Pacino de Bonaguida.

${ }^{25}$ F. ALMARCHE VÀZQUEZ, "Mestre Esteve Rovira de Chipre”, Archivo de Arte Valenciano, 1920, pp. 3-13.

${ }^{26}$ El documento es recogido en X. COMPANY, J. ALIAGA, L. TOLOSA i M. FRAMIS, Documents de la pintura valenciana..., pp. 302-306. En la misma publicación es atractivo consultar los contratos de aprendizaje atendidos por Pere Rovira, y relativos a Alfons y Arnau, hijo, este último, del difunto pintor Bernat de Camprodón (IDEM., pp. 322-323).

${ }^{27}$ Para profunditzar en esta y otras cuestiones relacionades con Starnina véase la tesis de Maria Palumbo.

${ }^{28}$ La recuperación de la crisis explosionada a mediados de siglo XIV se empieza a percibir a partir de los años setenta de la centuria y revierte de modo muy positivo sobre el período internacional. David IGUAL LUIS, "Gran comerç i petit comerç a la Corona d’Aragó. L'exemple de Valencia a la baixa edat mitjana”, Imago Temporis, Medium Aevum, vol. III, 2009, pp. 490-505.

${ }^{29}$ J. HINOJOSA MONTALVO, Llibre de Privilegis de la ciutat d'Alacant (1355-1450), Universitat de Valencia, 2008, p. 20 i ss. i ID., "el port d'Alacant durant la Baixa Edat Mitjana", Congrés d'Estudis del Camp d'Alacant, Alacant, 1986, pp. 215-228.

${ }^{30}$ El puerto de Valencia se complementa en este contexto con los de Dénia y Alicante, que también tuvieron una notoriedad reconocida: J. GUIRAL, Valencia, puerto mediterráneo en el siglo XV (1410-1525), Ed. Alfons el Magnànim, València, 1989, pp. 414-132. D. IGUAL LUIS, Comercio e industria en las ciudades mediterráneas, Revista d'Història Medieval, n. 8, 1997, p. 379; ID., "Red portuària y control marítimo en el reino de Valencia (siglos XIII-XV", Annliese NEF (ed.), Les territoires de la Méditerranée, Presses Universitaires de Rennes, 2013, pp. 51-53. Para otras referencias bibliográficas y valoraciones véase D. IGUAL LUIS, "La identidad marítima de las sociedades mediterráneas. Datos y reflexiones a partir de la Valencia bajomedieval", L. GALLINARI y F. SABATÉ I CURULL, Tra il Tirreno e Gibilterra, un Mediterraeo iberico?, vol. I, Cagliari, Milano, Roma, 2015, pp.439-467 (consultado on line, DOI 10.7410/1148).

${ }^{31}$ Jaume Mateu debió ser una figura notable, pero no deja de ser una de las más oscuras. Su perfil junto al establecido para los Gonçal Peris permite entrever fisuras o vacíos que reclaman nuevas precisiones y una revisión de los estilos individuales y colectivos, que todavía hoy se antoja difícil de precisar. Cfr. J. ALIAGA MORELL, "El taller de Valencia en el gótico internacional”, M. C. LACARRA DUCAY (ed.), La pintura gótica durante..., Op. cit, p. 207-241

${ }^{32}$ X. COMPANY, J. ALIAGA, L. TOLOSA i M. FRAMIS, Documents de la pintura valenciana..., vol. I, p. 332, doc. 570. Nicolau reconoce una deuda de 20 florines, avanzados por el tesorero de Alfons el Vell, marqués de Villena, por los trabajos que debía hacer en el coro de la catedral de Valencia.

33 Remito también para estos y otros datos documentales a la reciente monografía sobre el pintor de C. LLANES DOMINGO, L'obrador de Pere Nicolau. L'estil gòtic internacional a València (1390-1408), Universitat de Valencia, 2014. 




Fig. 3. Pere Nicolau, Retablo de Sarrión (Teruel), Museo de Bellas Artes de Valencia

bien sabido, su estado de conservación no es bueno. Hay que tener en cuenta que algunos autores expresan dudas sobre la autoría de este conjunto, con lo cual la imagen de Nicolau se llegaría a diluir en un espacio laberíntico que engulliría también otras figuras contemporáneas.

La configuración de un taller importante y las múltiples colaboraciones entre pintores, habituales en los talleres medievales, ${ }^{34}$ pero que parecen extremarse en el caso de la escuela valenciana del Internacional, 35 benefician todavía hoy la confusión de sellos estilísticos, creando un concierto artístico que, pese a todo, no arruina la armonía de los resultados y no desmiente el atractivo global de gran teatro del gótico internacional valenciano. ${ }^{36}$

El pintor del retablo de Sarrión, fuese o no el mejor Pere Nicolau, nos permite conocer a un maestro delicado en el tratamiento de las formas que, sumamente evanescentes, trabaja mediante la evaporación o succión del volumen de las figuras. Estas resultan amparadas por un bastión cromático valioso, que alegra los cuerpos dibujados, en un anhelo franco, y quizás también mistificador, que frena su espiritualización excesiva al mismo tiempo que hace posible constatarla. Con todo, el color tiñe hoy las composiciones y fija imágenes,

\footnotetext{
34 Muy de valorar también la reciente aportación de F. RUIZ QUESADA. "Una obra documentada de Pere Nicolau per al rei martí l'Humà. El políptic dels set Goigs de la cartoixa de Valldecrist", Retrotabulum. Estudis d'art medieval, n. 8. 2013, p. 2-43, y especialmente interesante para el tema que comento.

35 Ya se referia al problema J. GUDIOL RICART, "El estilo internacional en Valencia, Pintura gótica”, Ars Hispaniae IX, Madrid, 1955, pp.131-156.

${ }^{36}$ M. HERIARD DUBREUIL, Un chemin essentiel du gothique international : Valence [tesis doctoral]. Paris, 1983. s. p.; que revierte en un libro de rara configuración: M. HERIARD DUBREIL, Valencia y el Gótico Internacional. Valencia, Alfons el Magnànim, 2 vols, 1987.
} 


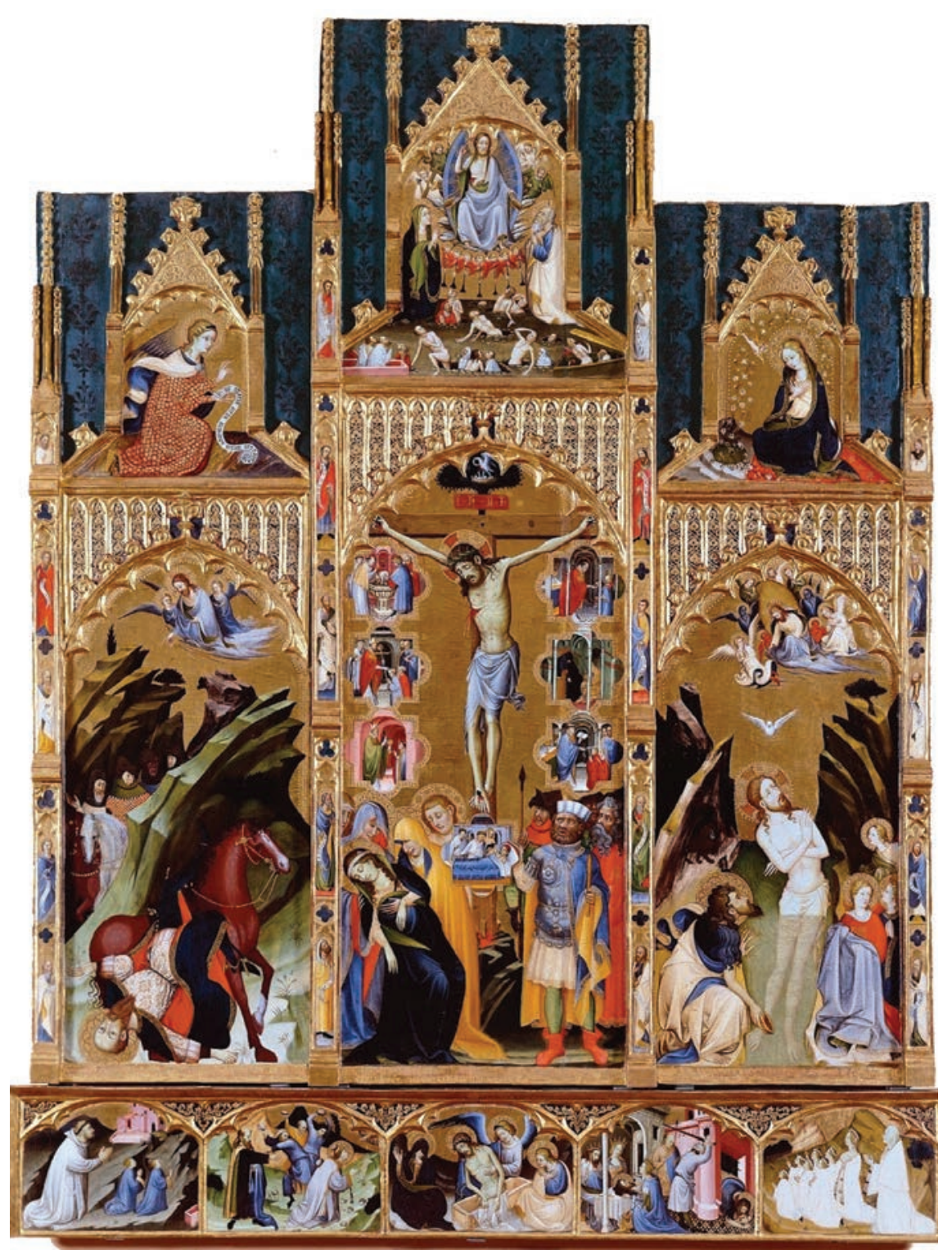

Fig. 4. Entorno de Gherardo Starnina, Retablo de fray Bonifacio Ferrer o de la cartuja de Portaceli. Museo de Bellas Artes de Valencia

que han sufrido restauraciones evidentes, perdiendo de la seguridad de trazo y belleza originales. Nicolau se aproxima a los parámetros establecidos por la escuela italiana, pero los traiciona en sus principales fundamentos, como lo hicieran algunos maestros franco-flamencos, fecundos creadores de ideas plásticas e iconográficas que parecen desmentir el peso de las figuras, y que encontramos afincados, sobre todo, en los territorios de la ilustración de manuscritos. ¿Cómo llegó Nicolau a ellos? y ¿Cuándo lo hizo? son cuestiones, no resueltas de modo suficiente, que inquietan la reconstrucción de su figura.

Un repaso de los documentos relativos al maestro Pere Nicolau nos descubre el gran interés que tuvo su relación con Marçal de Sas, o de Sax, bien manifiesta a partir de 1399. Marçal, maestro posiblemente originario de la región de Sajonia, llegaría pronto al contexto valenciano, coincidiendo su aparición con la de Nicolau, dentro de los primeros años 90 del siglo XIV. ${ }^{37}$ Desde el inicio debió pesar su verosímil raigambre germánica, aludida en un interesante documento de mayo de 1396, que nos permite considerarlo un buen conocedor de los modelos centro-europeos y franco-flamencos. Marçal debía ocuparse de las pinturas de pincel de la Sala Mayor de la Cámara del Consejo secreto de Valencia ${ }^{38}$ Entre otras figuraciones se ocuparía de representar un Juicio Final, un Paraíso y un Infierno, además de un ángel custodio que protegería la ciudad de Valencia y otras figuras que debían rogar por ella. Es preciso advertir que el mismo mes y día, el 20 de mayo de 1396, Pere Nicolau también cobraría por unas tablas destinadas a este ambiente conocido como Cambra del Consell Secret. 39

En torno a 1395, quizás algo antes, Valencia y el marco peninsular hispano, celebran el arribo del florentino Gherardo di Jacopo, más conocido como Gerardo Starnina. ${ }^{40}$ Su actividad adquiere relieve al ser el introductor de las densidades específicas de un singular tejido italianizante de difusa raigambre giottesca, que prolonga en apariencia el discurso trecentista y se amplia gracias a la aportación de otros pintores italianos relacionados con su actividad y promoción. Aunque no es la única pieza vinculada a la estancia valenciana de Starnina, la importancia y casi perfecto estado del retablo de fray Bonifacio Ferrer, realizado para la cartuja de Portaceli y hoy en el Museo de San Carlos de Valencia, ha enmarcado buena parte de las discusiones sobre este aspecto [fig.4]. ${ }^{41}$ Un buen análisis de la obra obligaría a realizar confrontaciones que solo pueden abordarse desde un planteamiento monográfico. Pese a la que considero todavía necesaria revisión de algunos

\footnotetext{
${ }^{37}$ En octubre de 1393 fue contratado para decorar el Portal de Serrans. Según los documentos, bastante escuetos, parece que debía dorar la clave de bóveda y pintar algunos ángeles X. COMPANY, J. ALIAGA, L. TOLOSA i M. FRAMIS, Documents de la pintura valenciana..., vol. I, p. 376, doc. 648-649. Poco después es Pere Nicolau quien, en septiembre de 1394 y en enero de 1396, debe pintar las claves de bóveda del Portal y una letras doradas a uno de sus lados (Idem, doc. 661 y 708).

${ }^{38}$ X. COMPANY, J. ALIAGA, L. TOLOSA i M. FRAMIS, Documents de la pintura valenciana..., vol. I, p. 403, doc. 715.

39 Algunas de las primeras referencias a esta obra se encuentran en J. RUIZ DE LIHORY, Diccionario biográfico de artistas valencianos, Valencia, 1897, p. 208, L. TRAMOYERES BLASCO, "La capilla de los Jurados de Valencia", Archivo de Arte Valenciano, vol. V, 1919, pp. 73-10o; J. SANCHIS SIVERA, Pintores medievales en Valencia, 1912, publicado de nuevo en J. SANCHIS SIVERA, "Pintores medievales en Valencia", Archivo de Arte Valenciano, vol. XIV, 1928, pp. 3-64. Véase también A. SERRA DESFILIS, "Historia de dos palacios y una ciudad: Valencia, 1238-146o", Anales de Historia del arte, vol. 23, 2013, número especial (II), pp. 333-367

${ }^{40}$ E. TORMO Y MONZÓ, “Gerardo Starnina en España”, Boletín de la Sociedad Española de Excursiones; Arte, Arqueología, Historia, n.18, 1910, pp. 82-101. Para otras referencias bibliográficas y consideraciones sobre el estado de la cuestión véanse los capítulos iniciales de la tesis de M. L. Palumbo, Il soggiorno di Gherardo Starnina in Spagna, Universitat de Barcelona, entregada en noviembre de 2015 y con lectura prevista entre diciembre y enero del 2016.

${ }^{41}$ Véase. M. L. PALUMBO, "Rappresentazione dei sacramenti e cicli cristologici nella pittura valenzana del gotico internazionale", a R. ALCOY I P. BESERAN (ed.). Imatges Indiscretes I. Art i devoció a l'Edat Mitjana, Barcelona, 2011, p. 121-132.
} 
aspectos, concuerdo con aquellos autores que han hablado del retablo como resultado de una realidad pictórica hibridada, que superpone algunas de las experiencias relevantes y más satisfactorias del momento, eludiendo los purismos estilísticos - entendidos como situaciones extremas del estilo-que permiten separar los modelos del norte europeo de los asociados a la vía italiana. Una obra que, en este sentido, se convierte en modelo de lo que fue la génesis del gótico internacional. Aunque existan multitud de situaciones intermedias la ponderación de este aspecto ante la compleja imagen del retablo me parece un paso obligado, ya que el estilo de Starnina incumbe a la obra pero lo hace en un grado reticente, que siempre ha dificultado la atribución taxativa al pintor florentino..$^{42}$

El concierto neo-giottesco que introducen, Starnina, recordado por Vasari, y algunos compañeros de viajey oficio, en los años noventa del siglo XIV, tuvo que convivir y confrontarse con las directrices de los talleres de Pere Nicolau y Marçal de Sas. Ello es posible porque, pese a sus peculiaridades de corte septentrional, estos pintores tampoco eran ajenos a los esquemas italianos. Se plantea un itinerario de naturalezas distintas, paralelo o cruzado, y sumamente atrayente, que ha llevado a evocar, acto seguido, el rol del antiguo maestro del retablo Gil, identificado no sin polémicas con Miquel Alcanyís. La identificación del mismo con el Maestro del retablo de la santa Cruz (v.1409), destinado a la capilla de los Pujades en el convento valenciano de Santo Domingo [fig.5], cierra un círculo que se enfoca y se desenfoca sobre los distintos niveles de italianismo que estuvieron al uso en la ciudad. No se olvide que el recorrido de Starnina desembocará de nuevo en Florencia, con un retorno a la ciudad toscana, situado en-



Fig. 5. Atribuido a Miquel Alcanyís. Retablo de la santa Cruz, Museo de Bellas Artes de Valencia tre 1401 y 1403 , no exento de consecuencias, ${ }^{43}$ pero que va a producirse no sin haber dejado rastro anticipado e innegable en el marco peninsular hispano.

A los pintores italianos, capitaneados por el casi mítico Starnina, se añaden, gracias a la documentación, algunos maestros llegados de las regiones del norte de Europa, de Bruselas y de Utrecht. Todavía quedan obras por distribuir correctamente y pintores pendientes de identificación, con lo que es posible que se puedan encajar algún día con alguna de las personalidades más desconocidas. ${ }^{44}$ Acto seguido, el gótico internacional valenciano se verá favorecido por una segunda nube de pintores, pertenecientes a una generación más joven y autóctona. Muchos de ellos son realmente apreciables por sus aportaciones. Nos permiten circunscribir la

actividad del ya mencionado Miquel Alcanyís, los Gonçal Perís, Jaume Mateu, Antoni Perís y algunos más.

En este rico panorama, en que todavía están vivos múltiples debates atributivos, mi deseo es inscribir la figura de Guerau Gener. Hay que otorgarle el lugar que le corresponde realmente en este entramado, ya que es una personalidad pictórica relevante que no quedó al margen de las dinámicas esenciales de la pintura valenciana. Es más, otorgarle un papel preciso será de gran ayuda para explicar estas complejas dinámicas, sin olvidar que su biografía artística lo convierte en una figura clave en la Cataluña del gótico internacional. Demasiado olvidado en muchos de los análisis realizados, Guerau, tuvo una oportunidad que no desaprovechó, ya que fue capaz de operar y de abrir vías de comunicación

\footnotetext{
${ }_{42}$ M. L. PALUMBO, Il soggiorno di Gherardo Starnina in Spagna..., A. DE MARCHI, “Gherardo Starnina, Profilo”, M. T. FILIERI (ed.), Sumptuosa Tabula Picta, Pittori a Lucca tra gotico e rinascimento, catálogo, Sillabe, Livorno, 1998, pp. 260-265

${ }^{43}$ M. L. PALUMBO. "Una tavola misteriosa: il Giudizio Finale di Monaco attribuito a Gherardo Starnina”, a R. ALCOY (ed.). Art Fugitiu. Estudis d'art medieval desplaçat, Barcelona, 2014, pp. 87-108.

${ }^{44}$ El retablo de la Caída de los ángeles rebeldes, que conserva el Metropolitan Museum de Nueva York, configurado como pequeño retablo dedicado a todos los santos, es una pieza de iconografía sobresaliente. Su autoría no ha podido ser determinada, aunque se han discutido algunas hipótesis. A mi parecer sigue siendo una de las incógnitas remarcables del arte vinculado al 1400. Su origen, situado en la Cartuja de Valldecrist, fundación castellonense del siglo XIV (1386), hace pensar en la estancia prolongada en el centro cartujano del rey Martí, Martín el Humano, junto a su esposa María de Luna, año 1401.
} 
artística en los dos mayores centros portuarios de la Corona catalano-aragonesa. ${ }^{45}$

\section{ENTRE BARCELONA Y VALENCIA}

De todos los maestros que se dan cita en Valencia, incluidos los de la primera generación, Guerau Gener, con una relación directa con Marçal de Sas y Gonçal Peris, documentada en el $1405,{ }^{46}$ quizás no sea el más conocido y estudiado de los pintores que llevamos mencionados, pero en modo alguno puede ser catalogado como una figura menor. Existen varias razones que me llevan a elegirlo para intentar esclarecer algunas de las conexiones artísticas entre ambas ciudades portuarias. Por un lado, la documentación lo vincula de modo incuestionable a encargos y talleres de ambos centros y sobre todo porque, además del demostrativo aparato documental, su actividad ha dejado rastros seguros de calado histórico-artístico muy valioso, especialmente en el ámbito catalán. Pese a los contactos innegables entre talleres y los pertinentes traslados de algunas obras, y a diferencia de muchos otros pintores, cuya actividad se reconoce tan solo en una de las dos ciudades, creo que se ha verificado de modo suficiente que Guerau se desplazaría de Barcelona a Valencia y de Valencia a Barcelona en más de una ocasión. ${ }^{47}$ Como intento demostrar más adelante, también fue un maestro dúctil, que alteró los ritmos creativos de su estilo a partir de las novedades que, entre el 1390 y el 1410, establecieron los nuevos sueños figurativos del gótico en ambas capitales.

La muy especial presencia de Guerau Gener en el marco catalán, donde se registra su actividad a través dos obras conservadas y documentadas, el retablo de santa Isabel y san Bartolomé de la catedral de Barcelona (1400-1401) ${ }^{48} \mathrm{y}$ el retablo del altar mayor de Santa María de Santes Creus (1407-1410), ${ }^{49}$ no debe dejar en el olvido su paso por tierras valencianas, ni desenfocar el peso de la actividad que desarrolló junto a algunos de los mejores pintores afincados en Valencia, tema que suele aparecer como correlato secundario de su actividad, excesivamente intangible, como demuestra el hecho de que durante mucho tiempo no se haya reconocido obra suya en el marco valenciano. Más adelante tendré en consideración alguna excepción.

Sin embargo, los documentos dan a entender que Guerau, ya capacitado como pintor, habría tenido ocasión de colaborar con representantes importantes de la escuela valenciana y, si mis teorías son ciertas, en dos episodios temporales distintos, entre los que pueden advertirse cambios substanciales en el trazado de su obra. Es decir, Guerau no se adapta a estas colaboraciones sin que incidan de modo claro en sus procesos creativos, originando esquemas que incorpora y que le permitirán las adaptaciones oportunas en sus proyectos ulteriores.

La creación de grandes retablos, vestidos por fantásticas ordenaciones de cromatismo brillante y atrevido, encuentran lugar en estos dos puertos de primer orden, que dan trabajo a un buen número de artistas, pero es Valencia la más especialmente enriquecida por un juego muy abierto, que concitó la presencia de pintores que se instalan más allá del italianismo local — heredado del mundo trecentistao de los primeros hechizos franco-flamencos. A la larga la llegada de las nuevas ideas pictóricas pudo ser general, pero su fecundación temprana en la Valencia de los años noventa del siglo XIV merece ser destacada.

Las ciudades portuarias fueron capaces de asumir su compromiso como centros productores y divulgadores, en un contexto meridional europeo en plena efervescencia, que intercambia y recibe sugestiones del norte con naturalidad y que muestra una buena capacidad de adaptación, al encauzar la pintura por caminos que, si bien preconizaban los registros italianizantes anteriores, no forzaban en términos absolutos. De hecho, en Barcelona, el italianismo pudo actuar como una barrera creativa que frenó los ritmos plásticos basados en una estilización excesiva, dando lugar, salvo excepciones, $5^{\circ}$ a obras formalmente singulares, marcadas por las tensiones del internacional, pero que, sin renegar del volumen de las figuras, se recreaban en ciertos usos del color, siguiendo esquemas de la tradición precedente. En esta predisposición atemperada se asienta el primer Lluís Borrassà y la pintura barcelonesa de los años noventa.

\section{Primeros pasos de Guerau en Valencia}

La obra de Pere Nicolau (1390-1408) no es ajena a una base italiana en la que trasparentan elementos de la tradición local y en la que, al mismo tiempo, se observa un conocimiento de las experiencias germánicas, aunque el perfil del pintor no coincida con ellas en lo más esencial, sobre todo si lo juzgamos a partir del retablo de Sarrión. Habría que desmenuzar sus aportaciones para observar cuales fueron sus modelos exactos. Una mirada cauta, por lo pronto, pone de relieve su intensa conexión con las opciones del más provocativo estilo internacional que, sin menospreciar algún elemento de proximidad al espectro germánico, plausiblemente asimilado a través de las sucesivas colaboraciones con Marzal

\footnotetext{
${ }_{45}$ La importancia del gótico internacional ha dado lugar a numerosas publicaciones y a una serie de exposiciones dotadas de sus respectivos catálogos: $L a$ impronta florentina y flamenca en Valencia. Pintura de los siglos XIV-XVI, València, 2007; Espais de llum, Generalitat valenciana, València, 2008; La edad de Oro del Arte Valenciano. Rememoración de un centenario. Valencia, Museo de Bellas Artes de Valencia, 2009; Camins d'art, Alcoi, $2011 ;$ Catalunya 1400. El Gòtic Internacional, Barcelona, 2012.

${ }^{46}$ En abril de 1407 Guerau Gener habría concluido un retablo destinado a la catedral de Valencia, en colaboración con Gonçal Peris (M. HERIARD DUBREUIL, Valencia y el gótico..., p. 58), pero la relación con este pintor viene de antes.

${ }^{47}$ R. ALCOY, “Guerau Gener i les primeres tendències del Gòtic Internacional en les arts pictòriques de les catedrals catalanes”, Lambard. Estudis d'Art Medieval, vol. VIII (1995), 1996, pp. 179-213.

${ }^{48}$ J. AINAUD DE LASARTE, i F.P VERRIÉ, La pintura gótica en la Catedral de Barcelona. Barcelona, 1942 (inédito "Premi Martorell”), copia en el Archivo Histórico de Barcelona (casa de l'Ardiaca).

${ }^{49}$ Abordaremos más tarde esta obra compleja, encargada en primera instancia al taller barcelonés de Pere Serra, que recibió pagos por el retablo en 1403 y 1404. ${ }^{50}$ Joan Mates y el primer Guerau Gener son una parte de esas excepciones, si no queremos detenernos también en la figura del llamado Maestro de las figuras anémicas, que ya hace tiempo propuse relacionar con un pintor vinculado a Mates, Pere Rovira (R. ALCOY i M. MIRET, Joan Mates, pintor del gòtic internacional, Editorial Ausa, Sabadell 1998, p. 56, nota 91 i p. 66 nota 123, y que como Esteve Rovira de Chipre, permitiría realizar lecturas que no avanzo, por ser todavía demasiado inciertas, sobre la que pienso pudiera ser la personalidad de este segundo, aunque primero en el tiempo.
} 
de Sas, nos hace penetrar en un arte que ha valorado, quizás a través de inciertas segundas manos, algunas de las aportaciones fundamentales del mundo creativo italiano. Esto se observa en algunas de sus composiciones y en algunas opciones iconográficas.

Por poner un ejemplo, en el retablo de Sarrión [fig.3], $y$ en el retablo de Bilbao, ${ }^{51}$ el pintor recurre al modelo de tumba cerrada, que aparece como pedestal del Cristo de la resurrección, apropiándose de un esquema que tuvo sus alternativas en la escuela florentina y que la escuela catalana precedente había obviado. ${ }^{52}$ En otras tablas se aprecia la divulgación de esquemas generados por la escuela neogiottesca y que Starnina, junto a otros pintores de origen italiano, ${ }^{53}$ debió contribuir a difundir en el marco peninsular hispano. ${ }^{54}$ Uno de los modelos más evidentes es el de la Dormición de la Virgen, visible para Starnina en las tablas de Chicago y Filadelfia. Se pueden examinar asimismo con éxito otras escenas, incluida la Anunciación, y la tabla central perdida, de la Virgen con ángeles, del retablo de Sarrión, que adoptan valores ya apreciados y sustentados en el marco italiano y meridional europeo.

Con todo, les tonalidades dominantes en la obra de Nicolau delatan un espíritu afincado en otra coyuntura artística, aquella que podría cualificarse de extra-italiana, foránea a las verdaderas preocupaciones de la pintura toscana y inquietada por la valoración de otros muchos aspectos que se vieron reflejados, hasta cierto punto, en la controvertida figura del Maestro del Bambino Vispo definida como alter ego de Starnina o, incluso en algunos casos, comodín del florentino y sus colaboradores [fig.6]. No olvidemos que en su en torno se sitúan también un Simone di Francesco y Niccolò d'Antonio que amplian los registros del italianismo peninsular.55

El nexo con la miniatura septentrional resulta evidente en el caso de Nicolau, pero habría que profundizar en la cuestión al tiempo que se valoran las realidades artísticas concretas a que el pintor pudo tener acceso por estos canales. La presencia en el contexto valenciano de manuscritos como el Roman de la rose de la Biblioteca Universitaria de Valencia, no es un dato menospreciable. Este tipo de obras sugieren la posibilidad de conexión con artistas llegados del marco parisino o septentrional, marcados por una dinámica cultura franco-flamenca que, en el fondo, es la que articula el lenguaje de Pere Nicolau, más allá de sus referentes compositivos y de alguna cita concreta, que pueda imponerse desde otros ambientes. En la misma línea habría que atender

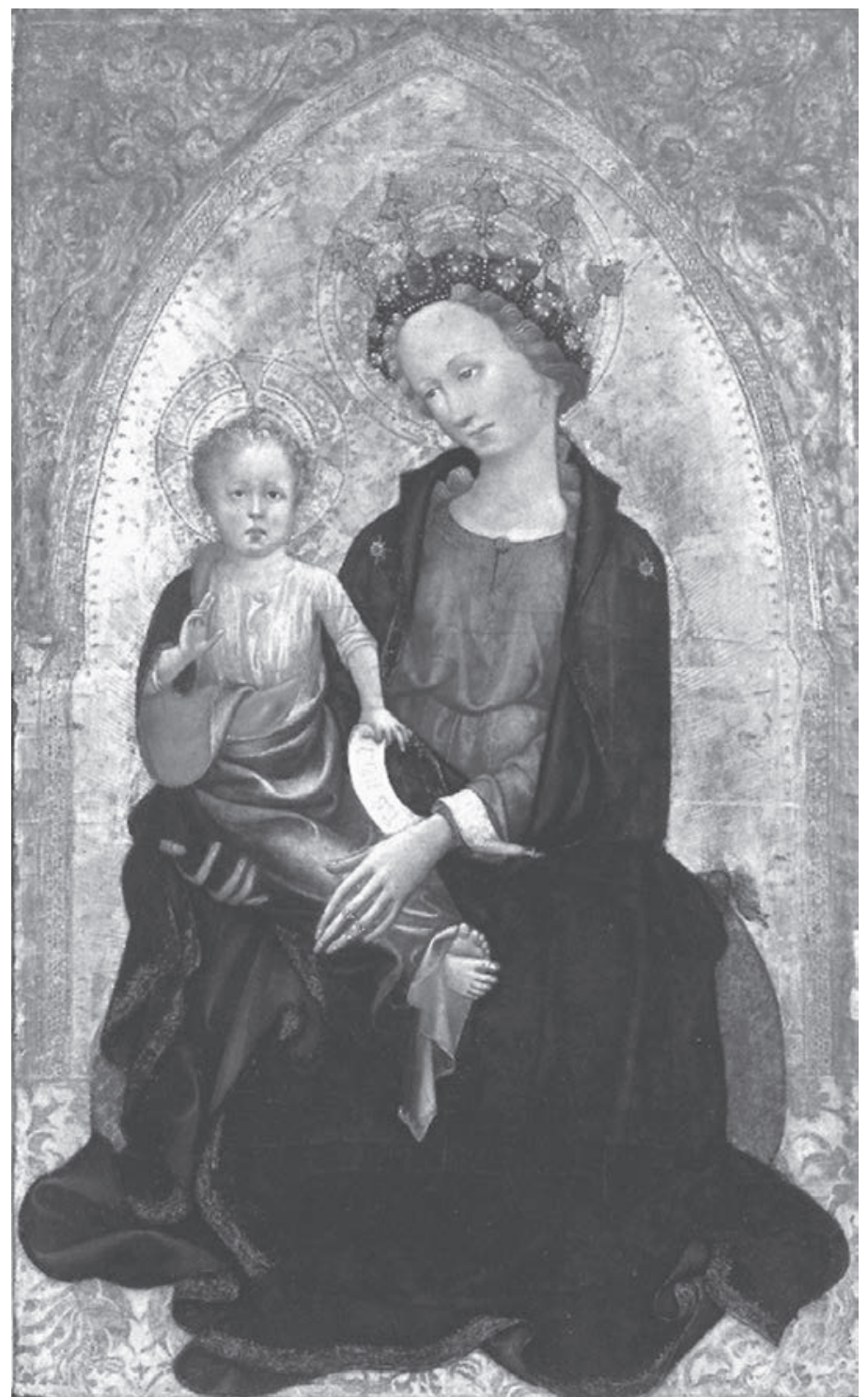

Fig. 6. Taller de Gherardo Starnina, Madonna col Bambino, Cleveland Museum of Art, Cleveland

a la llamada del pintor de Brujas, Jacques Coene. Un tema complejo en el que no voy a entrar ahora.

Sin intención de agotar un argumento tan extenso como este, advertiré que el estilo de Pere Nicolau debió estructurarse e hibridarse de distintos modos y aparecer, a lo largo de los años noventa, como una realidad tangible, sólida, que resultaría fundamental en la formación del primer estilo de

\footnotetext{
${ }^{51}$ A. M. GALILEA ANTÓN, La pintura gótica española en el Museo de Bellas Artes de Bilbao: catálogo. Bilbao, Museo de Bellas Artes de Bilbao, 1995. pp. 88-103. ${ }^{52}$ C. LLANES DOMINGO, L'obrador de Pere Nicolau, València, Universitat de València, 2014, figs. 5 i 5 b.

53 No puede olvidarse el nombre de Antonio Veneziano

${ }^{54}$ Starnina, mencionado como Gerardus Iacobi, pintor de la ciudad de Florencia aparece en distintos documentos del año 1395, como autor de un retablo pagado por Pere Macip, rector de Ènova, en la diócesis de Valencia, como testimonio y nombrando procuradores a Joan Stefano y Simon d'Estagio, mercaderes en Valencia: X. COMPANY, J. ALIAGA, L. TOLOSA i M. FRAMIS, Documents de la pintura valenciana..., vol. I, pp. 388 y 398 , pero también como autor de una pintura dedicada a la Pasión, destinada a la Capilla de San Salvador de la catedral de Toledo, obra que pintaría con Nicola d'Antonio (J. VAN WAADENOYEN, Starnina e il gotico internazionale.... M. HÉRIARD DUBREUIL, "Découvertes: le Ghotique à Valence (I)", L'Oeil, n. 234, 1975, pp. 12-19. Tema comentado también por otros autores y, en extenso, en la tesis de Maria Palumbo.

55 J. Van WAADENOIJEN, “A proposal for Starnina: Exit the Maestro del Bambino Vispo?", The Burlington Magazine, CXVI, n. 66, 1974, pp. 82-91 (estudio ampliado en el libro: IDEM., Starnina e il gotico internazionale a Firenze, Istituto Universitario Olandese di Storia dell'Arte, Firenze, 1983 algunas de cuyas conclusions puden contraponerse a las de M. BOSKOVITS, “Il Maestro del Bambino Vispo: Gherardo Starnina o Miguel Alcañiz?", Paragone Arte, vol. 26, 1975, n. 307, pp. 1-16, También interviene en el debate: F. SRICCHIA SANTORO, "Sul soggiorno spagnolo di Gherardo Starnina e sull'identità del Maestro del Bambino Vispo", Prospettiva, 6, 1976, pp. 17-29. John K. G. SHEARMAN, “The internationalism of Florentine Gothic art”, Max SEIDEL L'Europa e l'arte italiana, 2000, pp. 143-156 Véase, para una relación más completa i comentada: M. PALUMBO, Il soggiorno...
} 


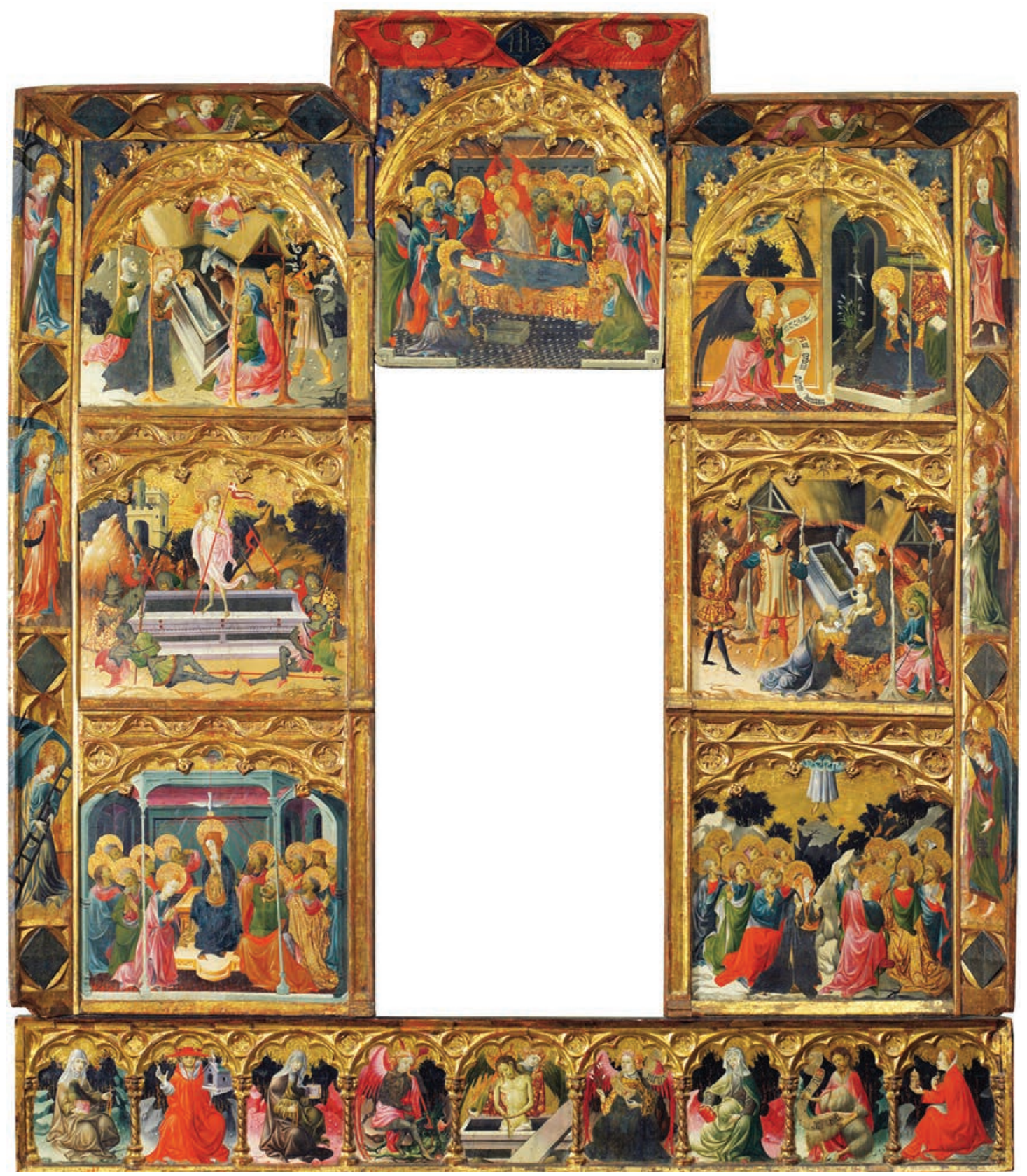

Fig. 7. Taller de Pere Nicolau, retablo de la Virgen, Museo de Bellas Artes de Bilbao

Guerau Gener, sumada a las sugestiones que este recibiría poco después, y señalado por el mismo contexto, de Marçal de Sas o de la escuela de Nicolau, a la que pertenecería su sobrino Jaume Mateu, entre otros notables maestros.

El retablo conservado en Bilbao, no documentado pero situado, por lo general, a fines de los años noventa, es según una parte de la crítica una de las primeras obras que nos habrían llegado del pintor [fig. 7], que también sería autor del retablo perdido de Albentosa (Teruel) del que se conocen fotografías. ${ }^{56}$ Sus características se reencuentran en trabajos posteriores, extensibles a sus seguidores más fieles.

En Cataluña, la obra que mejor refleja este primer contexto figurativo valenciano del Internacional, es el retablo de Santa Isabel y san Bartolomé de la catedral de Barcelona (1401) que fue encargado a Guerau Gener por Bartomeua Bou [fig.8], viuda de un Francesc de Sant Climent, ${ }^{57}$ que también es conocida como fundadora de un beneficio de san Bartolomé, de $1397 .^{5^{8}}$ La obra se destinaba a una de las capillas destacadas del claustro catedralicio y que, situada en

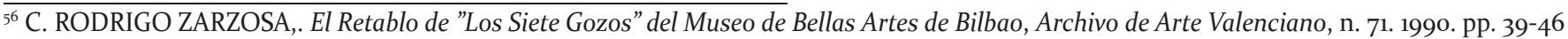

${ }^{57}$ Aunque existen distintas ramas de los Sant Climent, también en Barcelona, y el nombre "Francesc" fue habitual en todas ellas (véase M. T. FERRER MALLOL, "Altres famílies i membres. L'oligarquia barcelonina", C. BATLLE i GALLART; M. T FERRER i MALLOL; M. C. MAÑÉ I MAS; J. MUTGÉ i VIVES; S. RIERA i VIADER; M. ROVIRA i SOLÀ, El "Llibre del Consell" de la ciutat de Barcelona. Segle XIV: les eleccions municipals, Barcelona, CSIC, Institució Milà i Fontanals, 2007, pp. 271-346, en especial p. 330-338) se ha considerado que este Francesc de Sant Climent, pertenecía a una de las familias más poderosas de la oligarquía urbana de Lérida que poseía, entre otras propiedades, por venta real, la jurisdicción completa del castillo de Sarroca, siendo propietarios a finales del siglo XIV, de Alcarràs, Montagut, Llardecans, Flix i la Palma (M. T. FERRER MALLOL, "La población d'Alcarràs, Montagut, Sarroca, Llardecans, Flix i la Palma, dominis dels Santcliment, el 1386", Estudis històrics i documents dels arxius de protocols, n.20, 2002, pp. 75-93).
}

${ }^{58}$ F. RUIZ QUESADA (coord.), Pintura II.... 


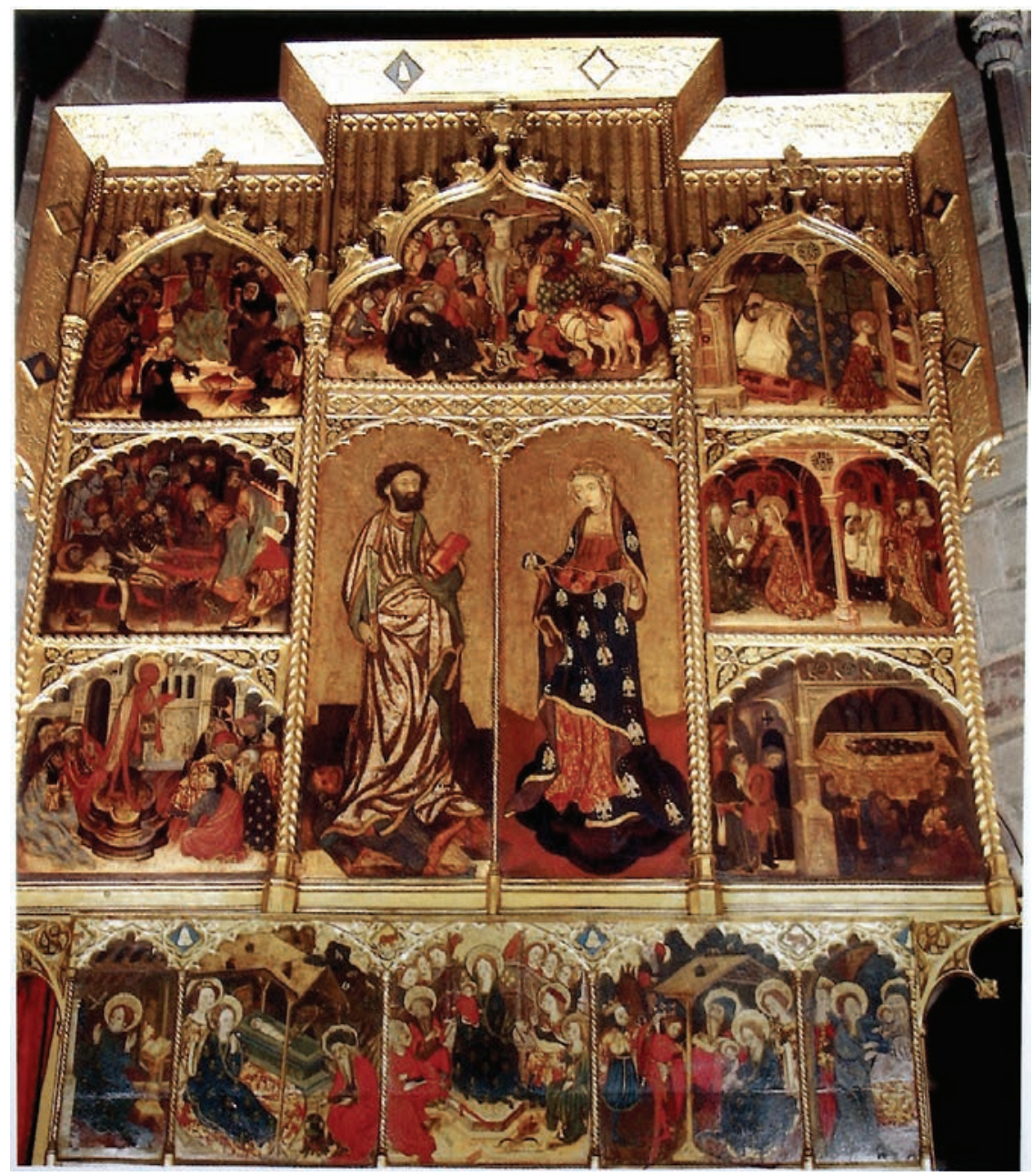

Fig. 8. Guerau Gener, Retablo de Santa Isabel y san Bartolomé, Catedral de Barcelona



Fig. 9. Taller de Pere Nicolau, fragmento de un retablo del convento de santo Domingo de Valencia, Museo de Bellas Artes de Valencia.

el ángulo sudoeste del recinto, se levantó bajo advocación de ambos santos. La capilla, algo mayor que las construidas en los años precedentes, fue cerrada al culto en 1578 y el retablo retirado y guardado hasta el año 1888, cuando se instalaría en su actual localización, una de las capillas abiertas a la nave lateral, del lado del evangelio, la dedicada a santa María Magdalena, obrada en 1389. La historia familiar se enrarecería después de la muerte de Francesc de Sant Climent, acaecida en los años ochenta. El endeudamiento del clan de los Santcliment leridanos se describe como uno de los hechos progresivos y más notorios de la realidad que los envolvía en este período. ${ }^{59}$

Sabemos poco de Guerau Gener antes de que recibiera el encargo de Bartomeua. Una anulación del contrato de aprendizaje pactado con Lluís Borrassà, a 26 de junio de 1391, nos informa que el trato, establecido para dos años, en que el pintor debía recibir 22 libras y la manutención, duró tan solo dos meses. Desconocemos la razón por la que, el joven Gener, que tenía a entonces 22 años, decidió abandonar el taller de Lluís Borrassà, pero es razonable pensar que Guerau, como se deduce del acuerdo económico, podía estar familiarizado ya con el oficio y deseoso de mejorar sus conocimientos sobre el mismo. ${ }^{60}$ El suyo no parece un mal convenio, si tenemos en cuenta la importancia del taller en que se inscribía, ${ }^{61}$ pero algo debió de ir mal o, quizás, debió abrirse un mejor horizonte en otro lugar. Es posible que Guerau abandonará así la escena barcelonesa, donde vuelve a encontrarse en 1399, cuando actúa como testimonio de la venta de una casa y algún que otro negocio, y recibe, poco después, el encargo para la catedral. Por tanto, aunque no se haya documentado su presencia en Valencia, entre el 1391 y el 1399, todo induce a pensar que sus pasos se dirigirían ya a este centro, donde le esperaban un cúmulo atractivo de nuevas experiencias pictóricas, que explotaría a su vuelta a Cataluña.

No hay que entender la pintura de Guerau como la de un simple imitador de Pere Nicolau, su planteamiento y ambición son otros, aunque en un principio compartiera con el pintor de Igualada, una voluntad de estilización muy apreciable, que persiguió también a otros maestros del período. Esta orientación de Guerau, bien concorde con las propuestas de Pere Nicolau, cobra densidades peculiares que obligan a presumir sobre una relación ya inicial en que también comparecen implicados Marçal de Sas y otros pintores del entorno.

Un interesante fragmento de retablo del convento de santo Domingo de Valencia, aproximado al taller de Nicolau —es sabido que el pintor había contratado en 1395 un retablo de san Lorenzo para esta fundación- ${ }^{62}$ nos permite establecer comparaciones con algunos de los resultados espaciales que se plantean en el retablo de santa Isabel y san Bartolomé [fig. 9], pero al

\footnotetext{
59 M. T. FERRER MALLOL, "La población d'Alcarràs, Montagut...",

${ }^{60}$ De aprender el oficio de pintor mejor de lo que él sabía. A. DURAN SANPERE, "Un deixeble del pintor Lluis Borrassà a la catedral de Barcelona”, Vida cristiana, vol. XX (1932-1933), p. 123, citado por J. Gudiol, Borrassà..., p.

${ }^{61}$ F. RUIZ I QUESADA, Lluís Borrassà i el seu taller, 2 vols., tesi Doctoral, Departament d'Història de l'Art, Universitat de Barcelona, 1998.

${ }^{62}$ El retablo, configurado como tríptico de $13 \mathrm{X} 12$ palmos, había sido contratado previamente, en abril de 1395, por Guillem Cases, pero, no mucho después, llegado el mes de octubre, Pere Nicolau asumía su conclusión. Por el trabajo a realizar se pagarían al pintor 40 florines de oro de Aragón: X. COMPANY, J. ALIAGA, L. TOLOSA i M. FRAMIS, Documents de la pintura valenciana..., vol. I, p.384, doc. 673 y pp.394-395, doc. 697; C. LLANES DOMINGO, L'obrador de Pere Nicolau ..., p.179.
} 
mismo tiempo deja margen para relacionar las tres escenas, consagradas a santo Domingo, con otros proyectos figurativos valencianos, que no excluyen la tarea de Marçal de Sas. Algunos detalles de la carpintería y el aprecio de las telas bordadas nos llaman la atención también en este sentido, vistiendo un horizonte plástico que Guerau Gener pudo conocer de primera mano antes de pintar el retablo de la catedral de Barcelona. ${ }^{63}$

En este, santa Isabel aparece con la cabeza descubierta, con el manto caído sobre la espalda, según la moda que se adoptó para algunas Madonas. San Bartolomé, pese haber sido despellejado, se nos descubre como gran figura áulica que acompaña sin problemas la sofisticada apariencia de la santa, coronada de flores. Se trata de dos imágenes en pie, pero visiblemente mayestáticas, construidas sobre la riqueza de sus mantos y el atractivo de un sugerente encaramiento, que rompe la frontalidad habitual en este tipo de presentaciones hagiográficas. Explicar este trabajo de Guerau a partir de la creatividad de Rafael Destorrents y de sus creaciones en obras como el Misal de Santa Eulalia (Archivo de la catedral de Barcelona) no me parece verosímil. No me lo parece teniendo en cuenta la cronología de formación de ambos maestros y los rasgos específicos de cada una de sus obras. Ello no implica que entre ambos no pudiera darse algún tipo de intercambio ni que la miniatura, en un sentido general, quede al margen de lo realizado en el retablo. ${ }^{64}$ Por el contrario, la ilustración valenciana brinda una información suficiente que encaja con la renovación planteada por Guerau, desde el mundo del retablo. Estos esquemas serían llevados también al marco aragonés por pintores como Gonçal Peris Sarrià a quien se concede el gran retablo de Santa María la Mayor de Rubielos de Mora (Teruel), estrictamente dependiente de los modelos relacionados con Pere Nicolau. Con todo, más allá de ambos y de sus cánones específicos, considero insoslayable la contribución de Marçal de Sas en la organización del los proyectos de Guerau.
Segunda etapa: los contactos de Guerau con Marçal de Sas y Gonçal Peris

La colaboración entre Marçal de Sas i Nicolau es un hecho que se documenta ya en 1399 y va a prolongarse al menos hasta 1404. Al año siguiente las colaboraciones de Marçal se documentan con Golçal Peris i Guerau Gener. El retablo del Centenar de la Ploma, hoy en el Victoria and Albert Museum de Londres, es un impresionante trabajo de equipo y la más deslumbrante y monumental de las obras conservadas del gótico internacional valenciano [fig. 1]. ${ }^{65}$ Nadie parece dudar, hoy en día, de la aportación de diferentes pintores a esta pintura de complejidad y ambición innegables. Sin embargo, una cuestión bien distinta es que todos vayamos a poder coincidir en la distribución de las manos y en el engarce de responsabilidades entre los distintos pintores que intervinieron en la realización del magnífico conjunto. ${ }^{66}$ Cualquier teoría que vaya a desarrollarse sobre este particular debe tener en cuenta numerosas variables y, entre ellas, no es la menor el modo en que deben jerarquizarse las intervenciones. No solo cuenta la distribución de manos por tablas, o fragmentos pictóricos aislables, hay que tener en cuenta las distintas tareas que se debían acometer, la organización del taller, por supuesto, y la distribución de los distintos quehaceres. Visto el retablo en diversas ocasiones no veo nada clara la posibilidad de una distribución, sea esta equilibrada o desequilibrada, de las distintas tablas que configuran el cuerpo central obra entre diversos pintores que trabajen de modo autónomo en cada una de ellas [fig. 10].

En mi opinión, un solo pintor debió hacerse cargo de la dirección del retablo, del planteamiento global del programa y del diseño específico de los contenidos de los plafones de este cuerpo principal. Para saber quien fue este pintor hay que atender ante todo al dibujo subyacente, que se hace visible también en superficie, cuando la aplicación del color es adecuada. En este sentido, la primera pregunta que debemos plantearnos ante este y otros retablos valencianos es si el dibujo se debe a un único pintor o a más de uno y en



Fig. 10. Marçal de Sas y colaboradores, Detalle de las escenas dedicadas a san Jorge, Retablo dl Centenar de la Ploma, Victoria and Albert Museum, Londres

\footnotetext{
$\overline{{ }_{3} 3}$ Abordé la cuestión atendiendo a sus vertientes iconográficas en R. ALCOY, “Guerau Gener i les primeres tendències...”, p. 179-213.

${ }^{64}$ R. ALCOY, "Guerau Gener i les primeres tendències..."

${ }_{55}^{6}$ C. M. KAUFFMANN, "The Altarpiece of St. George from Valencia”, Victoria and Albert Museum Yearbook, n.2, 1970, pp. 65-96.

${ }^{66}$ Cfr. M. DE MIQUEL JUAN, “El gótico internacional en la ciudad de Valencia, el retablo de san Jorge del Centenar de la Poma”, Goya, 2011, p. 191-123.
} 
que grado colaboraron los otros maestros que intervienen en la obra. No es necesario que la respuesta se decante en términos absolutos $\mathrm{y}$, como es lógico, se pueden derivar muchos matices de un análisis pormenorizado, que llevará a admitir frecuencias plásticas diferenciadas si hace al caso.

Ahora bien, la cohesión del conjunto será siempre favorecida por un diseño capaz de ponderar la coherencia de distintas plasticidades y estilos que puedan congregarse en la superficie de la obra. A mi entender de no existir este trabajo de base, y una subsiguiente coordinación, los resultados estarían lejos de la excelencia que todavía hoy reconocemos al retablo del Centenar, de forma unánime, aunque este “todavía” pueda ser circunspecto a unas épocas determinadas. Este trabajo no puede dedicarse a debatir y explicar la obra del Centenar, pero plantear esta reflexión era necesario porque afecta a otros temas colindantes que nos conducen al sistema de colaboración entre pintores, sea en Catalunya o en Valencia, afectos a de la biografía de Guerau Gener.

A mi parecer entra dentro de lo aceptable que fuese el cabeza de taller, y máximo responsable de la obra, quien ejecutase el dibujo, con los paréntesis o excepciones que puedan hacer al caso y que deberán ser definidos minuciosamente en otros estudios. La predela del conjunto, por ejemplo, muestra variedades notorias respecto a la forma de ejecución del resto de la estructura pintada. Por cultura figurativa y relevancia, creo que el maestro principal pudo de ser Marçal de Sas, encargado de resolver el diseño de la iconografía y las partes principales del retablo.

La defensa de esta hipótesis, que ya suscribí hace tiempo, ${ }^{67}$ no me impide considerar que otros pintores allegados al mismo se ocuparan del acabado cromático o, incluso, que su participación pudiera delimitarse, en casos concretos, que deberían explicarse con todo detalle, también a la preparación y dibujo de una parte restringida de las tablas. Me parece evidente que no fue Pere Nicolau quien se hizo cargo del dibujo de las tablas, —si Pere es el maestro de Sarrión- pero, habida cuenta de la frecuente colaboración de este pintor con Marçal, la posibilidad de un encuentro o de desencuentro específico, a raíz de esta empresa, aparece como un hecho al que debe atenderse.

Un factor a considerar, sea más o menos pertinente la forma de explicar la falta de implicación de Nicolau en el conjunto, es la división de tareas que se advierte a partir de lo documentado para otras obras en que se suman los conocimientos de ambos pintores. En los documentos que se refieren al retablo de la Virgen del altar mayor de la iglesia del monasterio de Portaceli (1403-1404), Pere Nicolau es el encargado de dar color, de dorar y pintar, y Marçal figura como responsable del dibujo. Si este fuese el caso, la distribución de tareas resulta muy interesante, aunque es evidente que a los respectivos obradores se pudieron sumar otros pintores más jóvenes. Entre los asociados, tanto a Marçal como a Nicolau, se contaran a algunos de los mejores representantes de la siguiente generación. No tiene sentido descartar que Guerau Gener conociera este contexto tan sugestivo como intrincado, en el que existió una gran cantidad de intereses en juego. No me parece fundada la atribución

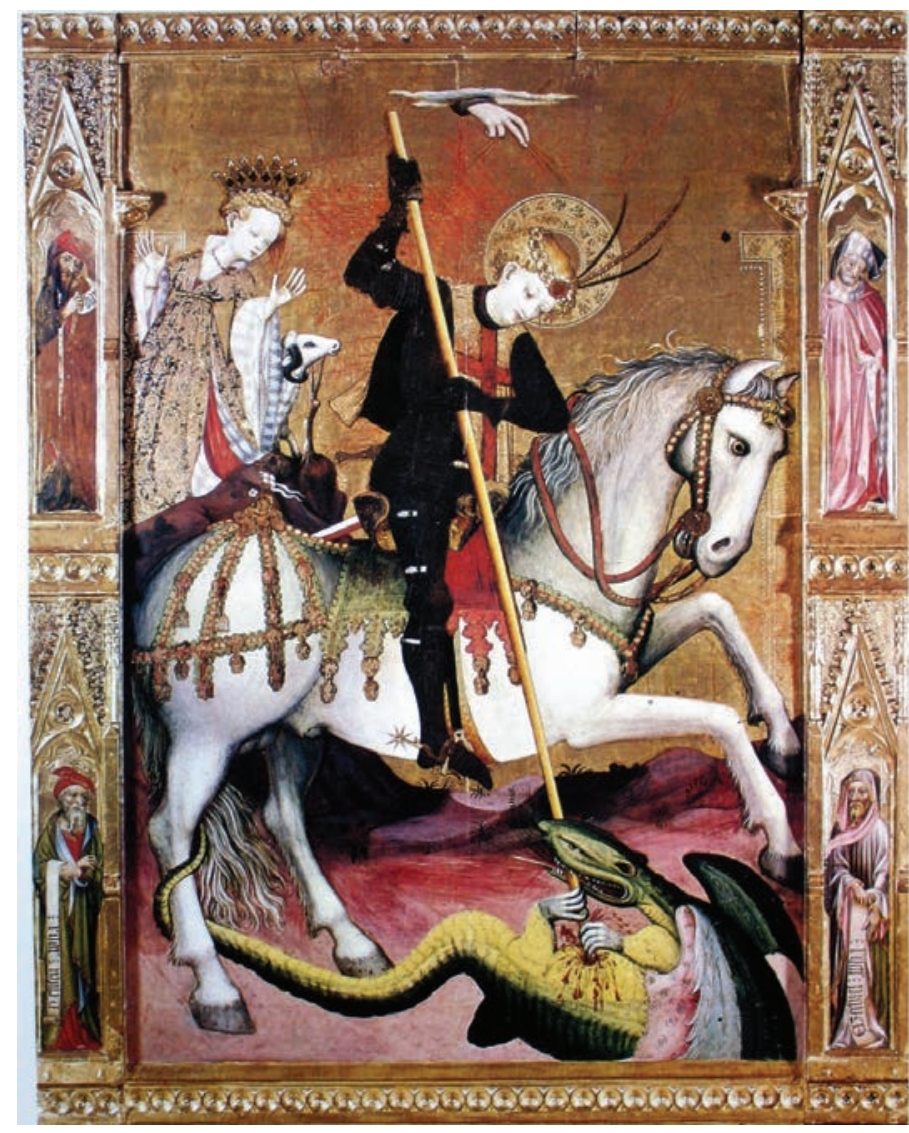

Fig. 11. Marçal de Sas y colaboradores, San Jorge y el dragón. Retablo dl Centenar de la Ploma, Victoria and Albert Museum, Londres

de una buena parte de las tablas del retablo del Centenar a Miquel Alcanyís. ${ }^{68}$ Sin poder abordar ahora esta cuestión específica y desarrollar esta idea, creo que antes de avanzar por este camino deben despejarse algunas de las incógnitas que limitan todavía los análisis del retablo de la Santa Cruz, una obra desigual en la que también podría reconocerse la participación de más de un pintor.

Todas estas consideraciones deben servir para apreciar mejor que, la asociación de un nombre a una tabla, o serie de tablas, pertenecientes a una obra bajo la responsabilidad de distintos pintores, es un riesgo que compromete un conjunto de deducciones en cadena, que pueden crear problemas importantes, cuando se trata de distribuir méritos entre los artífices que colaboraron en obras diversas. A mi parecer, la Duda de santo Tomàs, tabla de la catedral de Valencia, nos sitúa ante una problemática de este tipo. La obra ha sido atribuida de forma reiterada a Marçal de Sas, pero confluye de modo muy directo con la segunda época de actividad de Guerau Gener con quien este maestro tuvo ocasión de colaborar. Por consiguiente, deducir el perfil de Marçal a través de esta única tabla puede haber oscurecido el panorama, tergiversando algunas conclusiones y empobreciendo, en definitiva, la verdadera dimensión de su trabajo.

En el retablo del Centenar, el cambio de escala entre la figura de san Jorge y el dragón [fig. 11] y el resto de las escenas, haría pensar en un cambio de dibujante, pero justo en este caso la solución podría apreciarse también como una

\footnotetext{
${ }^{67}$ R. ALCOY, “Guerau Gener i les primeres tendències del Gòtic Internacional..., pp. 179-213.

${ }^{68}$ Antiguo Gil Master, tratado por Ch. R. POST, en A History of Spanish Painting, Cambridge, Ma., Harvard University Press, vol. VIII, t. 2, 1941, pp. 647-652 i vol. IX, t. II, 1947, pp. 765-768, fue identificado con Alcañiz por L. DE SARALEGUI, "Comentarios sobre algunos pintores y pinturas de Valencia", Archivo Español de Arte; XXVI, 1953, pp. 237-252. Véase el estado de la cuestión descrito en la tesis doctoral de Maria Palumbo.
} 




Fig. 12. Marçal de Sas y colaboradores, Batalla del Puig. Retablo dl Centenar de la Ploma, Victoria and Albert Museum, Londres

forma querida de distinción de la casa principal, aquella que permite fijar la advocación del retablo y que se dispone con acento aclaratorio en el genial marco discursivo, apreciable para el resto de la obra. Entonces, y en este sentido, la tabla puede entenderse como una interrupción deseada, que despliega recursos fundados en la tradición precedente con argumentos nuevos. El carácter caballeresco, de retrato ecuestre, hasta cierto punto simonesco, se impone sobre la acción tópica del santo encargado de humillar al dragón en un paisaje sucinto, replegado para dar asiento a la princesa y a la oveja que la acompaña. Sobre estos elementos pesa todo el oro del fondo y una iconicidad distinta a la de la batalla que vemos más arriba. La mano divina se abre paso en este espacio dorado para bendecir al santo caballero y su acción.

El complejo tejido de la batalla del Puig (1237), en que Jaime I es ayudado por san Jorge a vencer a los infieles, enfatiza todavía más la visión estática y algo aplanada de la escena del enfrentamiento con la bestia [figs. 11 y 12]. El cielo del retablo, concebido como lugar para la llegada extemporánea de los fieles, da aposento a la imagen de la Virgen con el Niño, y se sitúa en la zona más alta, como un canto a las aspiraciones del cristiano y a la salvación que vence a todo tipo de conspi- raciones diabólicas. La sensibilidad de un pintor, con grandes capacidades para el dibujo, aflora en esta esplendida escena en que el manto pictórico se acomoda bien a la trama ofrecida. Por desgracia la aplicación del color en retablos como el de Sarrión y otros relacionados con Nicolau no se aprecia en todas sus calidades y hay que recurrir a otros pintores de su entorno para saber hasta donde pudo llegar un maestro especializado en este terreno. En el retablo de la Virgen del altar mayor de Portaceli, Nicolau se había encargado del dorado y de la pintura y Marçal del dibujo.

Sabemos que Marçal de Sas, hacia 1405, se había asociado con Guerau Gener y Gonçal Peris. La diferenciación entre dos Gonçal Peris no deja de complicar un panorama ya bastante intrincado y obliga a cuestionar nuevamente toda una serie de atribuciones. ${ }^{69}$ La clarificación de los estilos de estos pintores es todavía insuficiente y, en su encuentro con la obra de Jaume Mateu, no parece explicada por completo. Un hecho significativo que me lleva a dar más importancia a las colaboraciones precedentes, fundamentales para la comprensión de la pintura valenciana del período. Tan absurdo puede ser a veces distribuir una pequeña tabla entre diversas manos como obviar esta posibilidad cuando lo exige la gran superficie de un retablo excepcional.

La realización del retablo de Centenar pudo prolongarse algunos años, pero la obra da la impresión de haber sido realizada en un plazo temporal bastante acotado. Cuando Guerau Gener llegó a Valencia por primera vez, en los años noventa, es posible que la obra no se hubiera trazado todavía, pero cuando se le documenta junto a Marçal, en 1405, es plausible que se estuviera trabajando en el conjunto. Los modelos que nos permiten entender el retablo de Santes Creus no son los del retablo del Centenar. Basta con comparar los modelos utilizados para los evangelistas de los respectivos coronamientos. En el caso catalán sobresale la el acogimiento cariñoso de los símbolos, en especial cuando se trata de animales, por parte de los evangelistas. Esta dimensión afable y graciosa, que permite que san Juan casi acaricie el águila y que san Lucas haga lo propio con el buey, al que enmarca el rostro con la mano izquierda, no se reitera en el retablo de san Pedro de Terrasa del taller de Lluís Borrassà, donde los evangelistas, pese a una buena predisposición para con los símbolos, se concentran en la escritura tomando las figuras del tetramorfo como acreditada compañía o eventual fuente de inspiración..$^{\circ}$

La distancia es neta por razones de iconografía, pero también debiera serlo atendiendo a los nichos estilísticos que se profundizan o engrandecen en esta época. Si en el retablo de santa Isabel y san Bartolomé, Guerau podía haber estado muy atento al tándem Nicolau-Sas, en el retablo de Santes Creus se cruzan otras realidades y se pone de relieve al mismo tiempo la maduración del pintor, cada vez más capaz de definir un estilo característico.

La tabla de la duda de santo Tomás de la catedral de Valencia resulta apta para la comparación con algunas de las escenas del retablo catalán [fig. 13].71 Quemada y de aspecto deformado en todo lo relativo al color, su dibujo surge como

\footnotetext{
69 Joan ALIAGA. Els Peris i la pintura valenciana medieval, Edicions Alfons el Magnànim, Generalitat valenciana, València, 1996. M. MIQUEL JUAN. "El retablo de San Miguel Arcángel de Gonçal Peris Sarrià de la catedral de Albarracín”, Rehalda: Revista del Centro de Estudios de la Comunidad de Albarracín, n.11, 2009, pp. 49-55; F. RUIZ QUESADA. "Del obispo Sapera a los linajes Pomar i Nadal. Gonçal Peris y los retablos de Puertomingalvo", Retrotabulum. Estudis d'art medieval, n. 5. 2012, pp. 2-58.

$7^{70}$ J. GUDIOL, Borrassà..., figs. 99-101. Véase también J. GUDIOL CUNILL, El pintor Lluis Borrassà, Barcelona, 1925, làms. LVI-LVIII.

${ }^{71}$ Publica buenas imágenes de la tabla X. COMPANY, La Época Dorada de la pintura valenciana (siglos XV y XVI), Generalitat valenciana, València, 2007, p. 6o-63.
} 




Fig. 13. Taller de Marçal de Sas, Tabla de la duda de santo Tomás. Catedral de Valencia

un modelo próximo para algunas de las figuras de los apóstoles que van a repetirse en las escenas del retablo de Santes Creus [fig. 14]..$^{2}$ Un franco expresionismo, que abunda en grandes rostros, muy plásticos, impositivos, y un impacto maleable de los volúmenes, que me obliga a considerar la notable aportación de Starnina y compagni en el contexto valenciano cercano al 1400, hacen de esta pintura una creación singular, reveladora en diversos sentidos para el análisis de la obra del monasterio cisterciense.

Esta y otras creaciones del mundo valenciano absorben una parte del legado del italiano que impacta de forma muy apreciable en la obra de Guerau Gener. Ello plantea algunas cuestiones inevitables que derivan de la transición entre las obras de ambos maestros. Cuando Guerau desarrolla estos efectos, Starnina ya ha abandonado el escenario valenciano, pero su herencia ha sido absorbida por distintos pintores y quedan las obras que le fueron encargadas. No hay que olvidar que las obras donde se reconoce mejor su impronta, hasta

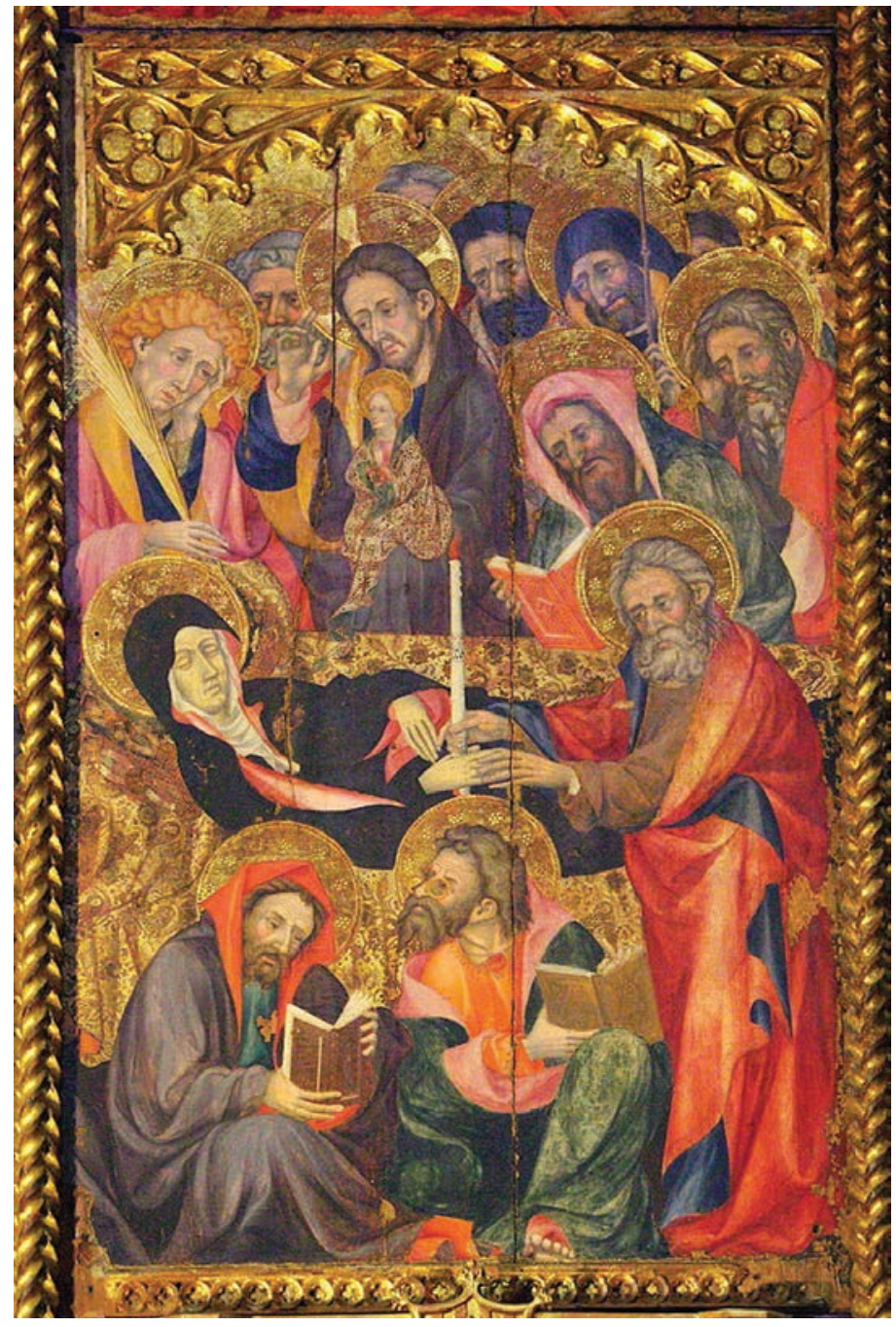

Fig. 14. Dormición de María. Retablo de Santes Creus. Catedral de Tarragona

alcanzar la posibilidad de esclarecer su intervención, son producciones sumamente adaptadas a la realidad artística local y a las exigencias del brillante formato internacional que se impone en esta escuela.

No puedo profundizar ahora en el tema de Starnina en el que se está trabajando desde hace tiempo ${ }^{73}$, pero es necesario advertir que ni el retablo de Bonifacio Ferrer,74 ni en la predela de Alpuente, ni el retablo de la Santa Cruz, son creaciones que puedan entenderse al margen del circuito de las interferencias florentinas en que los pintores catalanes y valencianos emplazan el neogiottismo de Starnina con los parámetros de un marco propenso a mirar al norte. En este cuadro debe encajar también las componentes germánicas, asociadas tanto a la herencia franco-flamenca como a la tradición de base italiana. Se impone consistencia a los esquemas de Pere Nicolau y se converge en cierto modo con los resultados de Gonçal Peris.

Guerau Gener podría evolucionar de modo paralelo a Gonçal recuperando elementos esenciales de la corporeidad de las figuras que pueden superar, en algunas obras, los que habían permanecido instalados en la escuela pictórica

72 R. ALCOY. "Pere Serra, Guerau Gener i Lluís Borrassà a l'entorn del gran retaule gòtic de Santes Creus", Butlletí de l'Arxiu Bibliogràfic de Santes Creus, Arxiu bibliogràfic de Santes Creus, vols. XV-XVI (1992-1993), Santes Creus, 1996, p. $65-98$.

73 Uno de los frutos de este trabajo es la tesis de Maria Palumbo, ya citada anteriormente.

${ }^{74}$ R. RODRIGUEZ CULEBRAS, "El retablo de Fray Bonifacio Ferrer, pieza clave en la iconografía sacramentaria del arte valenciano", Archivo de Arte valenciano, 1978, XLIX, pp. 12-17. Rodríguez Culebras no considero el retablo como obra de Starnina pero insistió en sus componentes toscanas. 


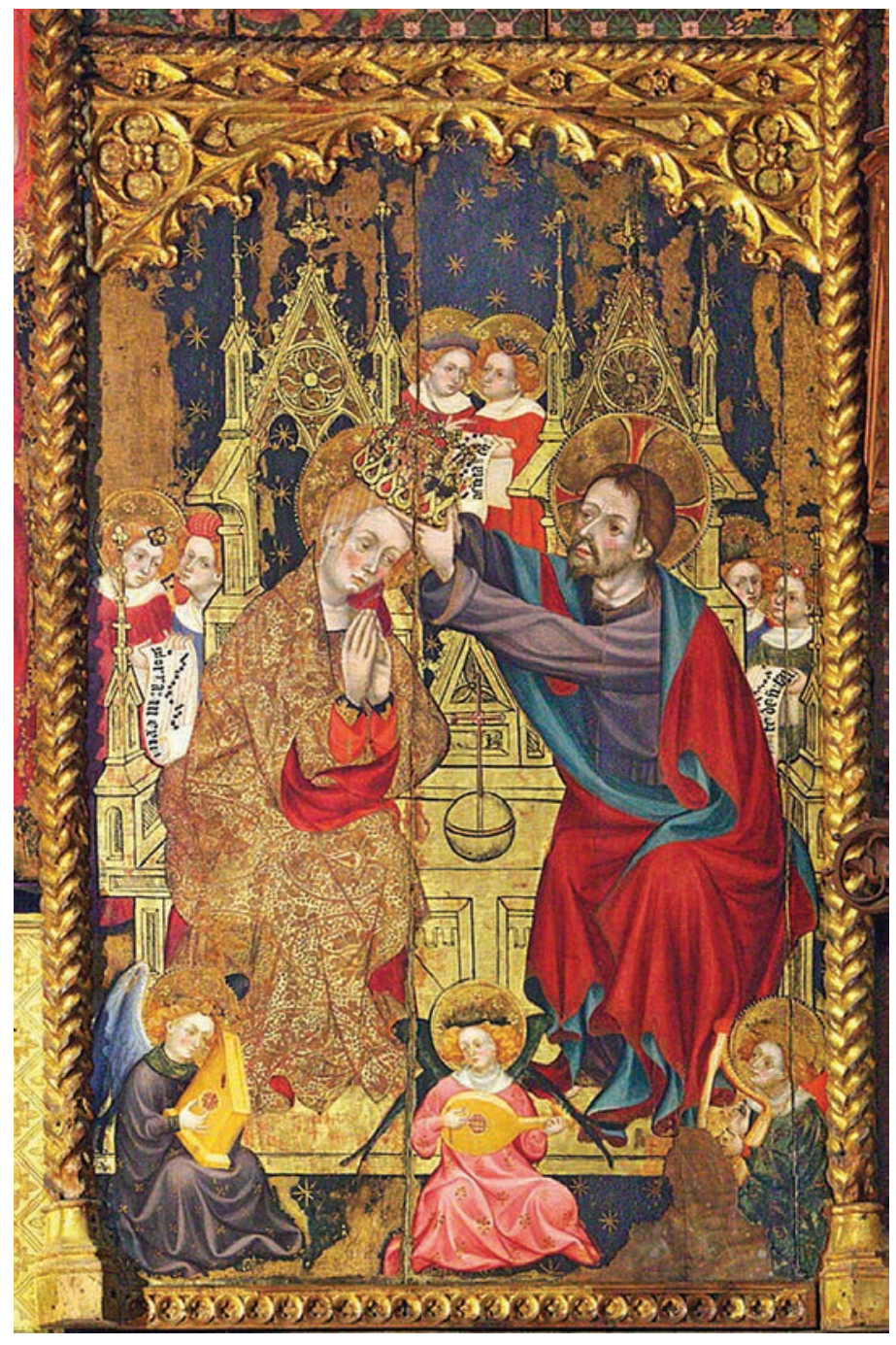

Fig. 15. Coronación de la Virgen. Retablo de Santes Creus. Catedral de Tarragona

catalana del segundo Trecento. Más penetrantes para las cuestiones espaciales, las del segundo cuarto del siglo XIV que las de la segunda mitad del Trecento, las pinturas se acomodan ahora a las sofisticaciones del Internacional. Pere de Valldebriga ya había acumulado soluciones muy loables por la contundencia volumétrica en rostros y cuerpos de las figuras, más allá de lo apreciable en las obras del taller de los Serra, aunque ambos fueran proclives a doblegarse en su momento final a las harmonías propias del 1400.75 Para entender el retablo de Santes Creus, la aportación de Gerardo Starnina se impone como un legado crucial, nuevo, pieza ineludible de un rompecabezas en que cada pintor gestiona su estilo y lo modifica para obtener los mejores resultados posibles en un marco competitivo y en el que, al mismo tiempo, resultaba obligado colaborar.

El retablo de Santes Creus es fruto, en su parte pictórica, de un cambio de registro, que resuelve algunas de



Fig. 16. Anunciación. Retablo de Santes Creus. Catedral de Tarragona

las inseguridades visibles en la primera fase creativa del pintor, representado por el retablo hagiográfico de la catedral de Barcelona, ${ }^{76}$ pero también de una proyección de los elementos e intereses que en este último se insinuaban de modo fehaciente. Las diferencias entre ambas creaciones, basadas sobre todo en una distinta plasticidad italianizante, se hacen notar, pero hay que ver también las raíces que se ejecutan sobre el plano expresivo y en el interés sostenido por los modelos iconográficos de carácter franco-flamenco y germánico, que se apoyan en unos mismos valores expresivos. Estos se funden ahora en los rostros de figuras más enfáticas y compactas. También se advierte una preocupación creciente por las arquitecturas, bien diseñadas en su detalle. Hecho muy claro en escenas como la Anunciación o la Coronación de la Virgen [fig. 15-16]. ${ }^{77}$ No creo que el dibujo de estas escenas sea debido a Luis Borrassà como tampoco creo que lo sea el de otros episodios del conjunto en sus

\footnotetext{
75 R. ALCOY, Pintures del gòtic a Lleida, Barcelona, 1990, pp.102-113.

${ }^{76}$ Se trata de un conjunto mixto organizado en cuatro grandes calles de tres niveles cada una, compuestas por dos escenas y el coronamiento con los evangelistas. En él se integraban tres grandes piezas escultóricas atribuidas a Antoni Canet, la Virgen con el niño y dos santos cistercienses. El conjunto se conserva dividido entre la catedral de Tarragona (capilla de la Virgen de Montserrat) y el MNAC (Barcelona), que alberga la calle procedente de la colección Fontana. Recientemente se ha recuperado también, procedente de colección privada, un que conserva un fragmento de la predela dedicado a las santas mártires. El ejemplo y precedente más próximo, aunque la temática no fuese la misma, pudo ser el gran retablo dedicado a san Pedro, procedente de Cubells, hoy dividido en diversas colecciones públicas y privadas. Se trata de un conjunto realizado en el taller de Pere Serra que, recordemos, también recibió el encargo, en primera instancia, del mueble destinado a Santes Creus. No descarto que la destinación del complejo retablo de san Pedro no fuera la iglesia de Cubells. Y me parece importante establecer el paralelismo con el antiguo retablo cisterciense tanto por la tipología del mueble como por el encargo de ambos conjuntos al taller de Pere Serra. 77 J. GUDIOL, Borrassà..., figs. 77 i 88.
} 


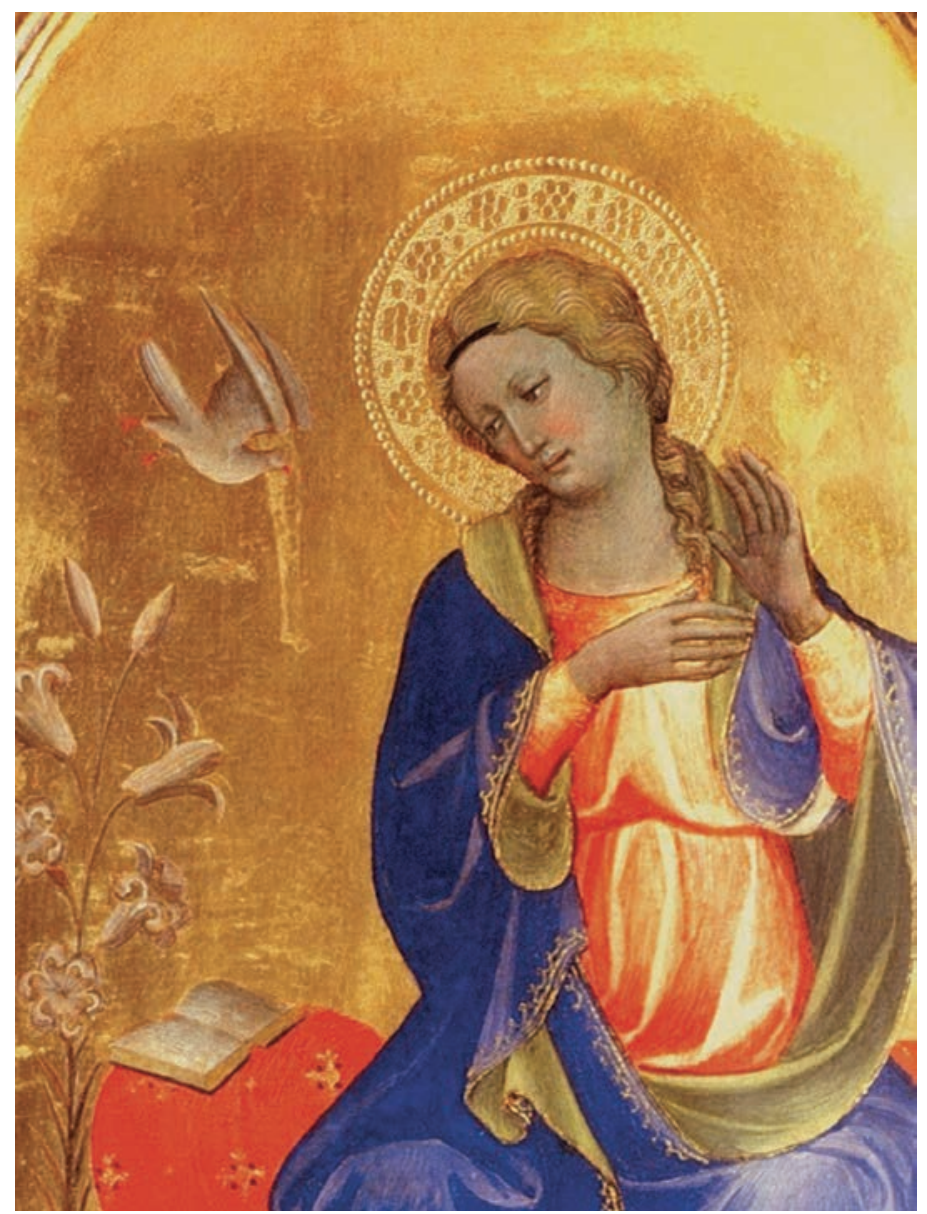

Fig. 17. Gherardo Starnina, Virgen de una Anunciación. Städel Museum, Frankfurt am Main

extremos primordiales. Sólo en la predela advierto algunos detalles del diseño que pudieran reclamar la participación de algún otro maestro, como ya indicara en su momento. ${ }^{78}$

A la espera de disponer de materiales de estudio suficiente, que puedan aclarar el estado del dibujo subyacente, y que corroboren el cambio que percibimos a simple vista, lo importante es constatar la distancia que separa el planteamiento de las imágenes de los resultados más característicos de Lluís Borrassà. Nada en la pintura catalana del momento, ni en el mismo Borrassà, aborda el registro de lo arquitectónico de esta manera. Tampoco en Valencia se describen esquemas de similar complejidad en las Anunciaciones que nos han llegado, aunque podamos evocar el cliché creado por Melcior Broederlam en Dijon. La mancha roja definida para el cuerpo del ángel y los cabellos rubios de Gabriel y María, pero también el juego arquitectónico basado en los arcos rebajados y arcos ojivales, el interés por las molduras o la figura del dios padre que aparece con el orbe en las manos son buenos referentes para aproximar este modelo al retablo catalán. Sin embargo, el recuerdo es mediatizado y han debido interponerse otros obras que buscaron un mayor equilibrio entre ambas figuras, escondieron el jarrón de los lirios y cambiaron el sentido de la filacteria que, en lugar de flotar hacia una Virgen encumbrada, desciende mientras ella baja la mirada.

En Valencia se imponen esquemas diversos al de Santes Creus, que evitan la frontalidad e imponen la lateralización del edificio que acoge a María, siendo inexistente en otras pinturas una arquitectura sobresaliente. Vale la pena señalar en el caso de la Anunciación de Santes Creus la coincidencia del gesto de la Virgen con la de la Anunciación del Städel Museum, Frankfurt am Main, fechada hacia 1404-1407 [fig. 17], vinculada a Starnina. El modelo debió ser bastante difundido pero es interesante que no aparezca reflejado en muchas de las obras valencianas de la época mientras se incorpora al retablo de Santes Creus. ${ }^{79}$ El plumaje azul de Gabriel florece como un tópico, reiterado en las alas de otros arcángeles anunciantes del mismo momento La capacidad y minuciosidad del pintor se revela a través de un dibujo seguro y de una buena adaptación compositivas de los modelos conocidos a los que incorpora ciertas novedades. La Epifanía rinde tributo a la composición de la Natividad e impone la solución del Niño totalmente desnudo, según el esquema adoptado por Nicolau, que bendice a los magos, sobresalientes por su rica indumentaria, por el juego de coronas y obsequios. La correspondencia con el arte de Borrassà —encargado de concluir el conjunto cuando desaparece Guerau- es una historia con dos direcciones, ya que tanto hay que considerar la huella dejada por este en el retablo como entender la huella que el retablo pudo dejar en él y, por consiguiente, también en su obra posterior.

En la resurrección de Cristo se advierte el abandono del modelo de Nicolau i su escuela, ya que se prefiere el relato vinculado al sepulcro abierto, que se acomoda asimismo al Misal de santa Eulalia de Rafael Destorrents y al Breviario del rey Martín, siguiendo la tradición más difundida, también en ámbito catalán desde la época de los Bassa.

Después de haber dado lo mejor de su pintura en el comprometido encargo de Santes Creus y sin haber podido concluir la tarea, Guerau Gener, desaparece en 1410. Lluís Borrassà se hace entonces responsable del conjunto, pero su contribución a esta obra no fue, a mi modo de ver, equipararse a la de Guerau y debió concentrarse en la conclusión de los acabados pictóricos, ya que ni la planificación de las escenas y ni el concepto de dibujo creo que le correspondan, al menos en términos generales. Ello no presupone que su aproximación a esta creación fuera inocua y tampoco, como advertía, que no hiciera mella lo ya realizado por Guerau en un pintor preparado y sensible como Borrassà, cabeza de un taller del que salieron obras bastante diversas, lógica consecuencia de su estructura compuesta.

La intervención de Lluís Borrassà en el retablo de Santes Creus es fundamental para entender su producción. A mi entender fue decisiva para dar cuerpo a su estilo al iniciarse la que podríamos conceptuar como su tercera y última fase creativa. Un vigory una plasticidad distintos que no existían en su producción de finales del siglo XIV y que tampoco me parecen apreciables en la obra que se sitúa entre este primer momento y el 1410. Por consiguiente, el encargo heredado es fundamental en un doble sentidoy pudo contribuir también al afianzamiento de ciertos aspectos del valencianismo que ya estarían presentes, hasta cierto punto, en el contexto barcelonés, una modalidad declinable de gran impacto expresivo que, pese a todo, no iba a instalarse por un igual en toda su producción. Podríamos afirmar que Guerau llevó a Borrassà a Valencia mientras Borrassà moldeaba los

\footnotetext{
${ }_{78}$ R. ALCOY. "Pere Serra, Guerau Gener i Lluís Borrassà..."

79 Puede verse algo parecido en la Anunciación del retablo de Santa María de Rubielos de Mora, pero la composición ha cambiado.
} 




Fig. 18. Detalle de la Dormición de María. Retablo de Santes Creus. Catedral de Tarragona

acabados de un retablo ambicioso en sus dimensiones, pero también en el terreno estrictamente pictórico.

Guerau Gener sacaría provecho de esquemas muy diversos sin quedarse anclado en ninguno de ellos. Pudo crear así escenas de una fuerza dramática innegable, como la Dormición de María. Esta parece heredera directa de la Duda de santo Tomás de la catedral de Valencia, si pensamos en el grupo de los apóstoles, pero también se halla sujeta a la descomprensión favorecida por el estilo de Starnina, que se advierte en la integración del volumen y en el recorte de las figuras que pesan individualmente en el espacio. Es pertinente su comparación con la Dormición del retablo del Burgo de Osma, un conjunto de calidad óptima que presenta rasgos sensiblemente próximos a los del retablo de Santes Creus, en especial en este episodio. En Santes Creus desaparece la parafernalia angelical. No hay ángeles que envuelvan la figura de Cristo, que parece embebida por el grupo de los apóstoles. Uno de ellos toca las manos de la Virgen yacente y pone entre ellas una vela mientras el cuerpo deja escapar el alma que se reviste de telas bordadas y doradas. La presión de los volúmenes ha cedido todo el espacio disponible y la trama es tan tupida que no quedan huecos, ni espacios vacíos que permitan articular un discurso distendido o similar al

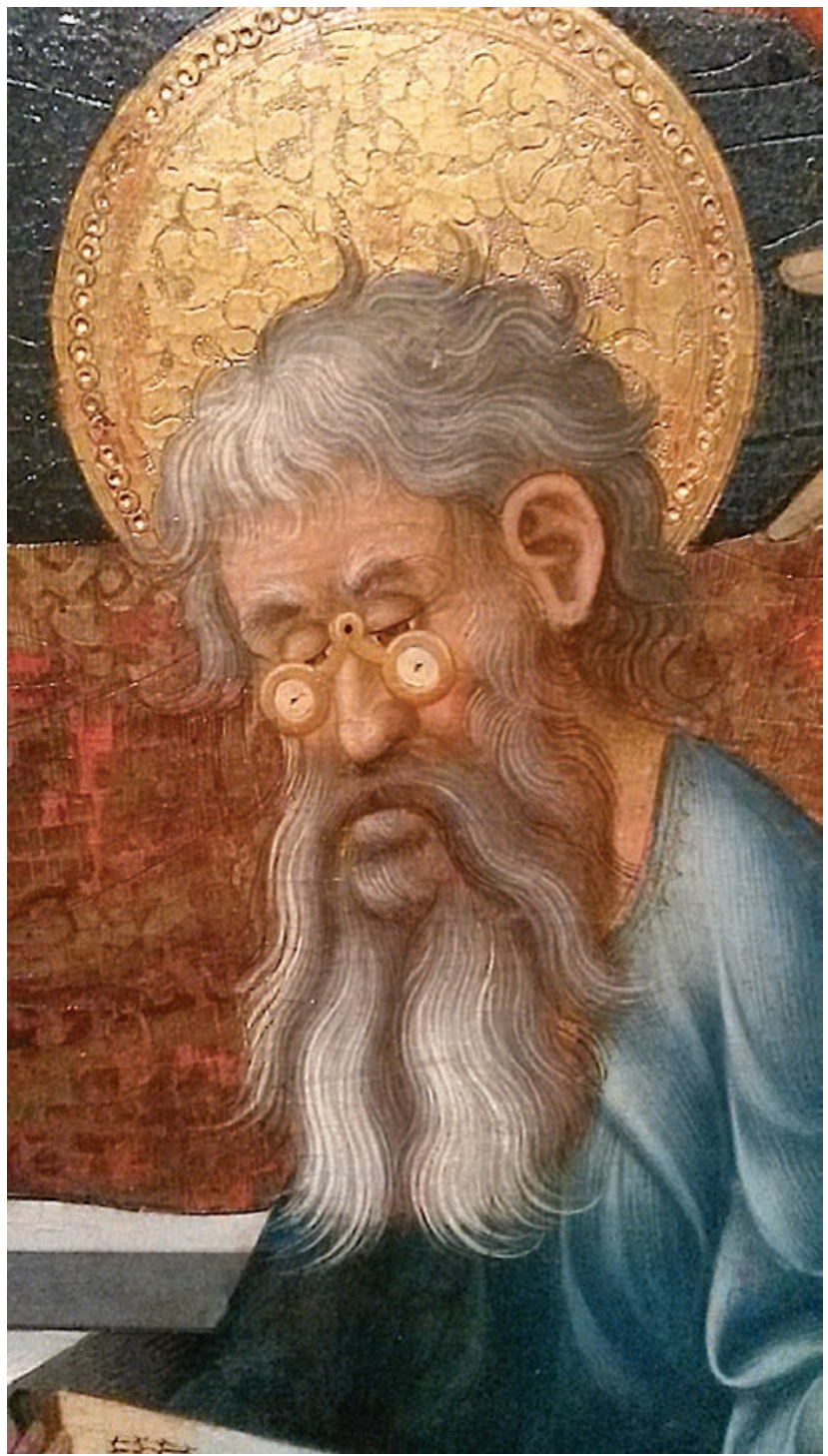

Fig. 19. Detalle de la Dormición de María. Retablo de Burgo de Osma. Museo Marès, Barcelona

del Burgo de Osma, en que entre la imagen de Cristo con el alma de la Virgen y los apóstoles se ha generado una distancia fundamental, que le permitirá abandonar la escena, pasándoles casi inadvertido. Todo es más estilizado, más frágil y quebradizo en el retablo del Burgo, pero el esquema básico es el mismo y el modelo se advierte común para las dos obras que, sin embargo, no tuvieron porque intercambiar nada en absoluto. Ni la forma de disponer los libros, ni el diseño de los nimbos, ni la concepción espacial y temporal son consonantes, pero las asonancias pictóricas sobre un fondo común resultan, a veces, profundamente significativas.

Si nos fijamos en los binóculos de uno de los apóstoles del primer término podremos compararlos tanto a los utilizados por Conrad de Soest ${ }^{80}$ como los apreciables en el retablo del Burgo de Osma. Es curioso advertir como Guerau distorsiona respecto a lo visible en estos modelos la forma de ubicar los ojos del apóstol lector, consiguiendo un efecto singular, aparentemente absurdo que, sin embargo, acrecienta la riqueza expresiva de la imagen creada frente a la mayor racionalidad puesta por sus compañeros de oficio, cuando se afanan en hacer coincidir el ojo con el círculo de las antiguas gafas plegables [fig. 18-19] .

$\overline{{ }^{80}}$ B. CORLEY, Conrad von Soest, painter among Merchant Princes. Harvey Miller, 1996. 
Los juegos de expresión germánicos vuelven en la Ascensión de Cristo o en la Pentecostés del retablo de Santes Creus, pero los equilibrios italianizantes no dejan de ponderar este balance original en manos de un pintor que recupera la fuerza de los volúmenes sin renunciar a las estilizaciones del gótico internacional. En la Coronación Guerau vuelve sobre algunos antiguos modelos catalanes, revisados a partir de los esquemas vistos en Valencia. Las ideas de Starnina se conjugan con las de los pintores del norte europeo y el resultado, atento a lo local, no podía dejar de sorprender.

\section{LOS SANTOS JUANES DE SANTAS CREUS}

Una tabla dedicada a san Juan Bautista y san Juan evangelista, catalogada como compartimento principal de un retablo del monasterio de Santes Creus, localizado según las fuentes en la antigua colección de Alfred P. Sloan en Nueva York, se integra en la catalogación de Alcolea y Gudiol como producción del círculo de Lluís Borrassà [fig. 2o] ${ }^{81}$ siguiendo lo ya planteado en 1953 por Josep Gudiol, en su monografía sobre este último, donde consideraba la proximidad al maestro, sin concluir sobre una indudable autoría del pintor, previo rechazo de la propuesta de Post, que había aproximado la tabla a la obra del Maestro de Rubió. La obra neoyorquina, ajena a los registros del citado anónimo, merece ser considerada de nuevo en este contexto. ${ }^{82}$ Francesc Ruíz, en el período en que elaboraba sus primeros trabajos sobre el taller de Lluís Borrassà, llamó mi atención sobre la proximidad de la pintura Sloan a Guerau Gener, pintor del que me ocupaba justo en aquel momento de mediados de los noventa. ${ }^{83}$ La procedencia de la tabla del monasterio cisterciense es, sin duda, un indicio a tener en cuenta, que favorece la aproximación a la realidad figurativa del retablo mariano, destinado al altar mayor del templo e incluso la especulación sobre un posible primer encargo a Guerau. El conjuto de los santos juanes hubiese podido destinarse a una de las capillas de la iglesia algo antes de la entrada en juego de Gener en los asuntos del retablo mayor ${ }^{84}$ En Santes Creus, al igual que sucediera en el vecino monasterio de Poblet, las capillas serían vestidas con importantes retablos góticos a lo largo de los siglos XIV y XV.

Sin que se adviertan a través de la imagen en blanco y negro de la tabla las mismas calidades visibles en el conjunto mariano de Santas Creus, y sin posibilidad de obtener materiales suficientes para una análisis estilístico pormenorizado, no voy a insistir ahora en la atribución a Guerau Gener. Con

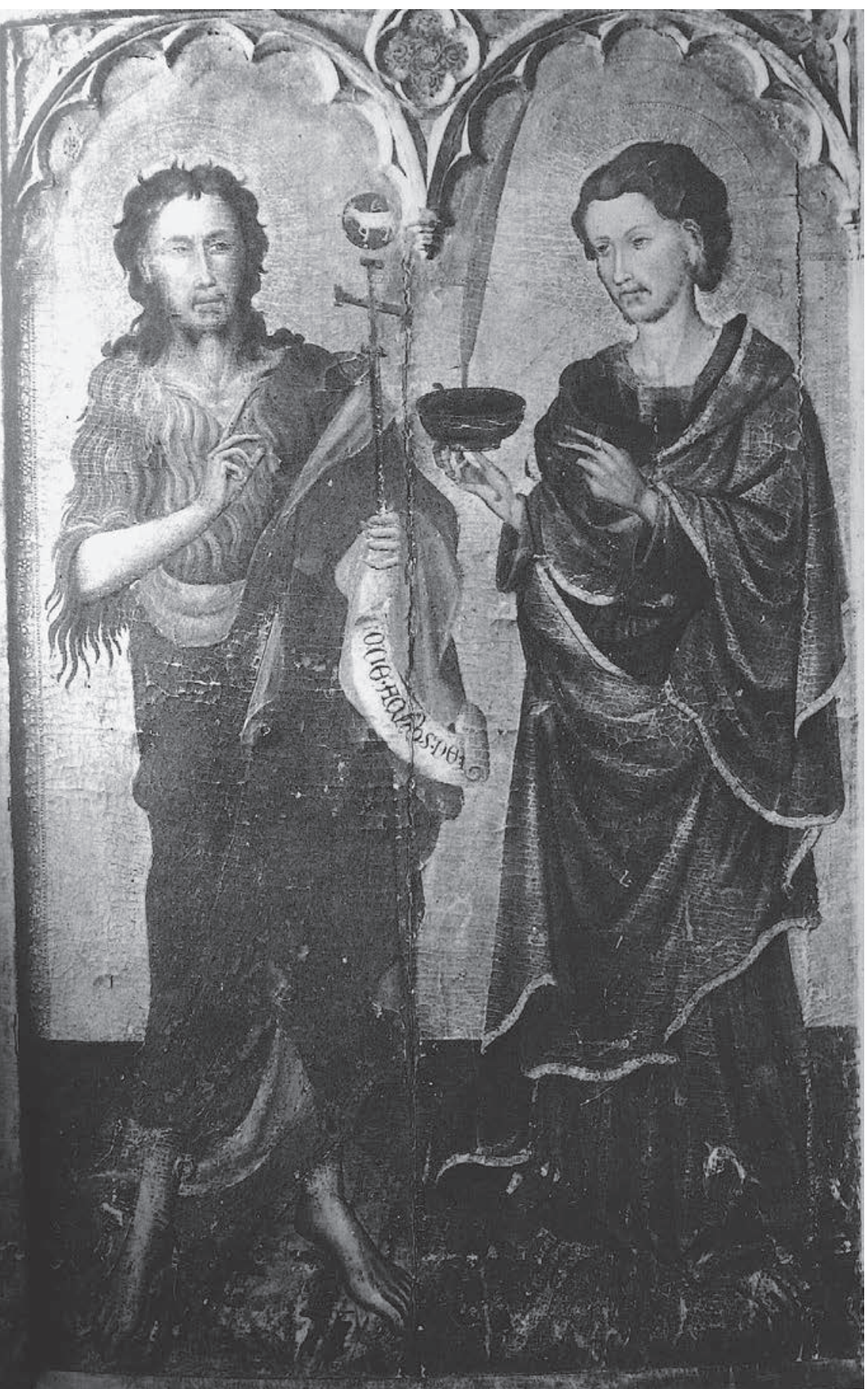

Fig. 20. Tabla de san Juan Bautista y san Juan evangelista, perteneció a la colección de Alfred P. Sloan, Nueva York

todo, no pongo en duda el atractivo del planteamiento y los nexos que nos conducen a un momento intermedio de la carrera del pintor, emplazado entre el retablo de la catedral [fig. 8] y el gran retablo cisterciense. Sin una observación directa de la pieza resulta comprometido sacar nuevas conclusiones, aunque quede claro que el modelo visible para el san Juan evangelista no es el mismo que se aplica en el retablo de la Virgen. También es significativo que se adopte para el

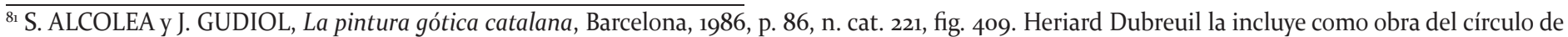
Lluís Borrassà M. HERIARD DUBREUIL, Valencia y el gotico..., vol. I, p. 95. vol . II fig. 261.

${ }^{82}$ J. GUDIOL, Borrassà, pp. 44-45 y 103, fig. 16, cat. IV. Ch. R. POST, A History of Spanish Painting, vol VI, p. 530, nota 2, vol. VIII, p. 570, fig. 265 , vol. XI, p. 376.

${ }^{8}$ R. ALCOY. "Pere Serra, Guerau Gener i Lluís Borrassà..." y R. ALCOY, "Guerau Gener i les primeres tendències...”.

${ }^{84}$ F. RUIZ, “Guerau Gener”, en F. RUIZ QUESADA (ed.), Pintura II....
} 


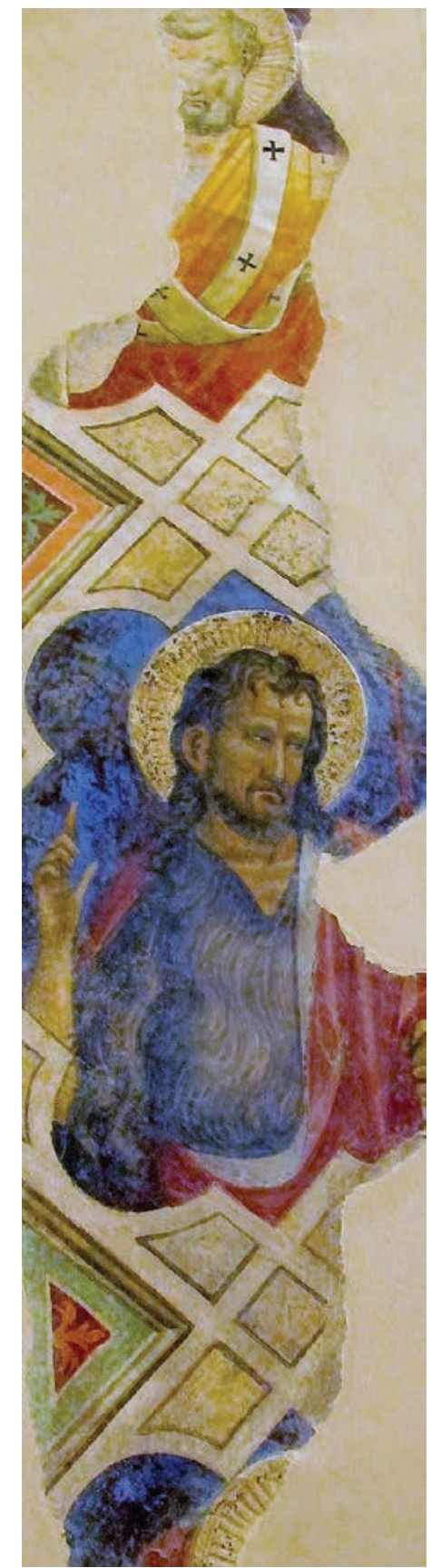

Fig. 21. Gherardo Starnina, San Juan Bautista, Museo de la Colegiata, Empoli

Bautista, de grandes pies y rostro hirsuto, un esquema de raigambre trecentista, en que es apreciable el recuerdo del flabelo con el Agnus Dei, situado ahora dentro de un pequeño círculo sobre una cruz metálica de largo palo. Sorprende su tamaño reducido que se aleja de la solución catalana más habitual, pero hay que tener presente que, a finales del siglo XIV, el tema debía evolucionar hasta desaparecer casi por completo ya en la primera mitad del siglo XV. ${ }^{85}$

Pese a este detalle local, es pertinente la comparación del Precursor de la tabla Sloan con el san Juan Bautista del Tríptico de Lucca de Gherardo Starnina, ya planteada por
Heriard Dubreuil, ${ }^{86}$ si bien cupiera pensar, asimismo, en el Bautista integrado en la tabla de la Virgen con el Niño de la Galleria de la Accademia de Florencia y en otras versiones starninianas dependientes de estos modelos. Muy en especial en la image de san Juan Bautista que comparece entre los fragmentos murales de Empoli [fig. 21], conjunto fundamental para la reconstrucción del maestro, en el que Starnina habría trabajado al final de su carrera (v.1408-1409). La tabla Sloan se halla anclada en un italianismo denso que configura cuerpos contundentes, menos maleables que los ideados por Guerau en el retablo mayor y alejados de las estilizaciones ideadas por el pintor para las figuras de santa Isabel y san Bartolomé de la catedral de Barcelona. Pese a ciertas coincidencias significativas, en comparación con otras obras, como el san Juan de Luca di Tommé (1355-1389), pone de relieve la proximidad de la tabla americana a los modelos toscanos del internacional.

En definitiva, no descarto el contacto del pintor de esta tabla Sloan con Starnina, atendiendo a una proximidad que ya indique en mis primeros trabajos sobre Guerau, pero es posible que deban valorarse también otras dimensiones del problema. La filacteria en manos del Bautista dista de ser la manejada por Gabriel en el retablo del altar mayor: estrecha y larga la del arcángel, alardeando de un recorrido sinuoso, gruesa y corta la que incluye el ECCE AGNUS DEI..., pronunciado por el Bautista. Tampoco coinciden los rasgos de la escritura. Si hay que valorar la hipotética inmediatez de ambas obras también me parecen necesario tener en cuenta los elementos que las separan.

Sin llegar a sus conclusiones, concuerdo con Gudiol en advertir algunas conexiones entre la tabla de los santos juanes y los valores plásticos visibles en el retablo del arcángel Gabriel, o de la Anunciación, que perteneciera a una de las capillas del claustro de la catedral de Barcelona. ${ }^{87} \mathrm{Gudiol}$ pensaba que ambas obras surgieron del taller de Borrassà. En cambio, en mi opinión, el conjunto catedralicio puede ser considerado como pieza fundamental del catálogo de un pintor distinto, que pudiera identificarse con Pere de Valldebriga. ${ }^{88}$ Por otro lado, cuesta mucho encajar la tabla Sloan en los esquemas del Borrassà mejor descrito y, en cambio, existen razones de peso para aproximarla a los contextos italianizantes valencianos, conocidos por Guerau, siendo notorios los nexos con el retablo Ferrer.

\section{UN SANTO DOMINGO Y UN POSIBLE SAN GIL, ENTRE OTROS ARGUMENTOS FINALES}

Un Santo Domingo de Guzmán del Museo Nacional del Prado de Madrid, rodeado por cuatro figuras, menores en tamaño, de santos, ha sido aproximado a Guerau Gener y a Gonçal Peris [fig. 22]. ${ }^{89}$ Se trata de una tabla al temple, de $155 \times 87 \mathrm{~cm}$, que se ha fechado en 1405 . La obra procedía de la colección Yakichiro Suma y fue adquirida por la Junta de Exportación en 1962. Se ha considerado que la pintura debió pertenecer a la capilla dedicada a santo Domingo en la catedral de Valencia, hecho que permitiría pensar en la autoría

\footnotetext{
${ }_{85}$ R. ALCOY, "Flabelos para el Agnus Dei del Bautista en el siglo XIV”, Cuadernos de Arte e Iconografía. Actas del primer coloquio de Iconografía, Coloquios de Iconografía (1988), Fundación Universitaria Española , t. II, n. 3, Madrid 1989, pp. 47-52.

${ }^{86}$ M. HERIARD DUBREUIL, Valencia y el gotico..., vol. I, p. 95.

${ }^{87}$ J. GUDIOL, Borrassà..., p. 45 y pp. 40-44.

${ }^{88}$ R. ALCOY, "Pere de Valldebriga o el Maestro..."

${ }^{89}$ Una fotografia de la pieza fue publicada por Tramoyeres en Archivo de Arte Valenciano en 1915
} 


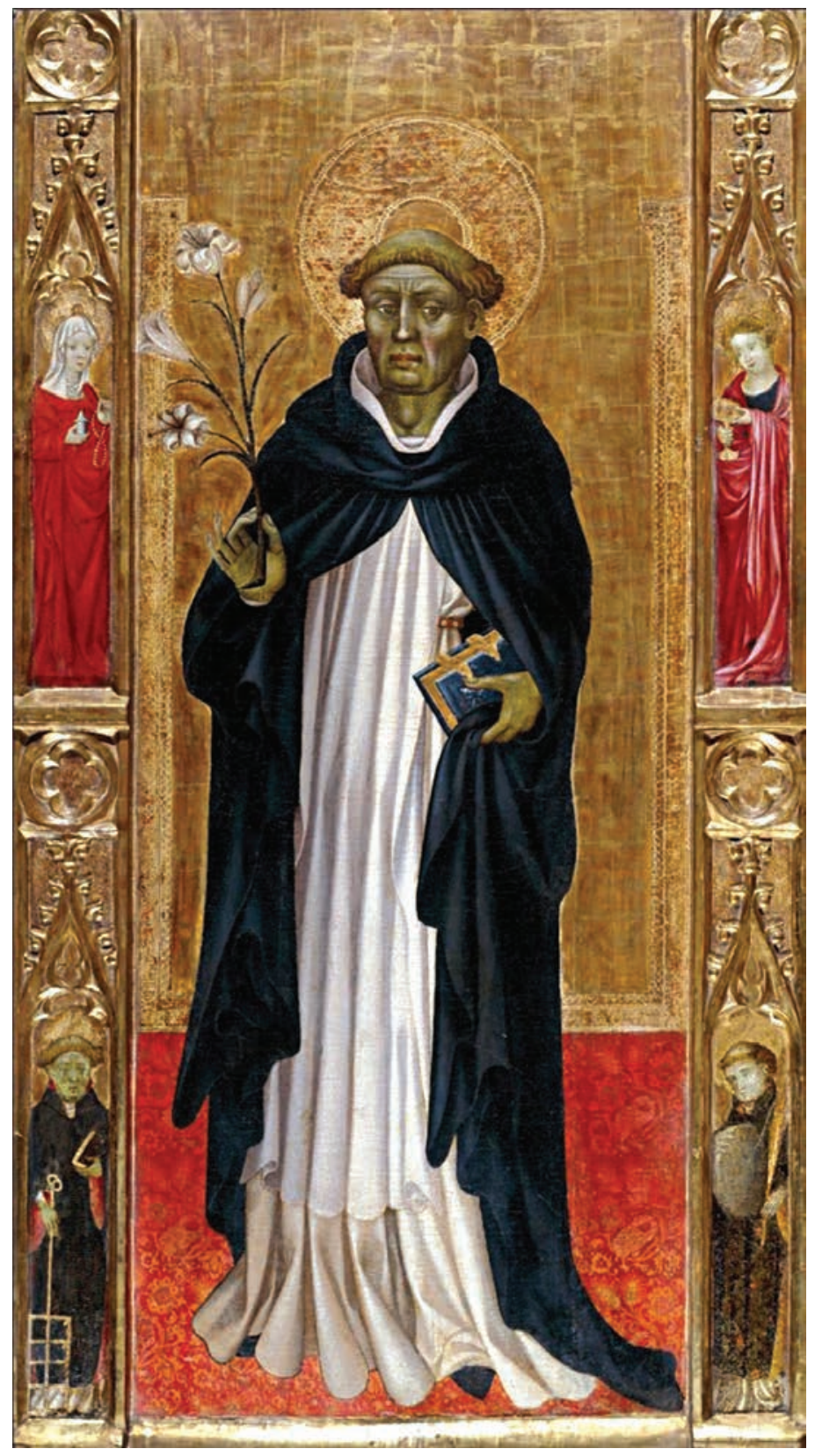

Fig. 22. Santo Domingo de Guzmán, fragmento de un retablo. Museo Nacional del Prado, Madrid

de Guerau i Gonçal en el momento preciso en que ambos colaboran con Marçal de Sas.

Santo Domingo de Guzmán con un libro y un manojo de lirios en las manos, comparece en el centro como titular de un posible retablo situado bajo su advocación. Un par de montantes situados a ambos lados dan cabida a dos santas, María Magdalena y santa Ágata en la parte superior, y a dos santos diáconos, san Lorenzo y san Vicente, en la inferior. Todos son portadores de atributos que facilitan su reconocimiento y Santo Domingo se identifica además por el hábito de la Orden de los Predicadores de la que fue fundador. Un análisis de la obra permite observar las características de un pintor que se integra fácilmente en la tradición valenciana, con buenas capacidades para el dibujo y un aprecio notorio de la expresividad de los rostros. Ello es evidente para la figura principal, pues la secundarias se hayan en peor estado de conservación y nos impiden un juicio preciso sobre algu-

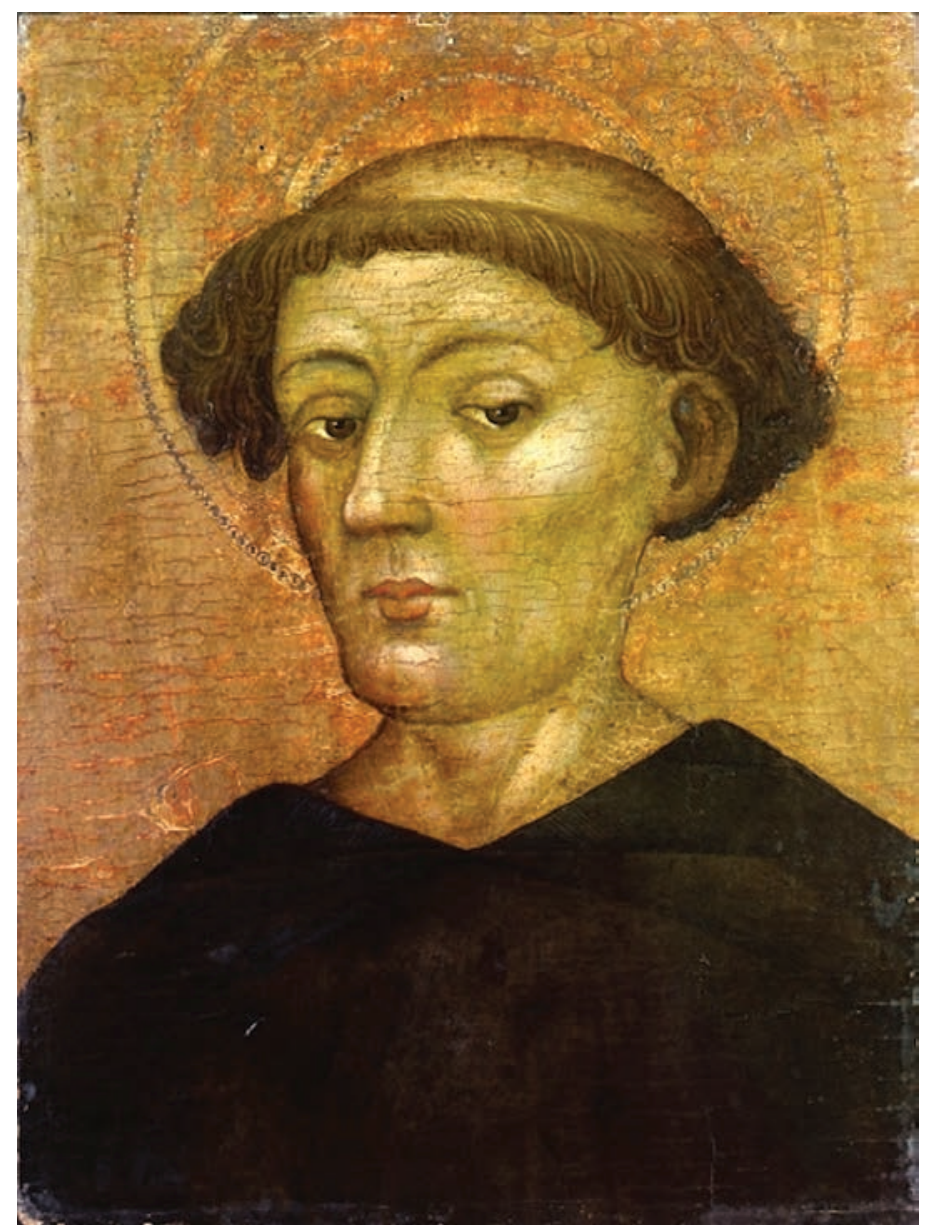

Fig. 23. Santo monje o San Gil (?), Museo de Bellas Artes de Bilbao

nas de sus calidades. La manera de configurar el nimbo del santo predicador y la estilización formal de los pliegues de su túnica blanca, esencial parte del hábito, el sentido del espacio y del entorno que hace vibrar la figura sobre el fondo dorado, no concuerdan en demasía con lo que hemos podido ver de la obra de Guerau Gener.

A mi entender, la pintura del Prado encaja mucho mejor con el discurso que viene atribuyéndose a los Gonçal Peris, sea a través de los conjuntos relacionados con el retablo de Santa Bárbara de Puertomingalvo, sea a través de otras obras similares, o inclusive del polémico retablo del Burgo de Osma del que hemos comentado ya la Dormición de la Virgen del Museo Marés de Barcelona, una tabla esplendida, como otras del mismo retablo. ${ }^{\circ}$ Por consiguiente, la tabla del Santo Domingo no puede ser atribuida a Guerau Gener ya que corresponde mucho mejor al estilo referido, vigente en la escuela valenciana todavía en la segunda década y tercera década del siglo XV. Si la intervención de Guerau se relega a las figuras de santos y santas de los montantes, el problema básico es el mal estado de esta parte de la pintura, en que la intervención del restaurador no disimula el exceso de los desperfectos que la dañan. No puedo entrar ahora en el debate sobre las fronteras que deben delimitar la aportación de las segundas generaciones del internacional en Valencia y que afectará los discursos tanto de los dos Gonçal Peris, como los de Jaume Mateu y Miquel Alcanyís, pero sean como sean estas fronteras, rígidas o flexibles, la tabla del Prado corresponde al contexto figurativo que se trenza en tierras

90 R. ALCOY. “Gonçal Peris (?). Dormició de la Mare de Déu. Compartiment del retaule de Burgo de Osma", Catàleg d'Escultura i Pintura Medievals. Fons del Museu Frederic Marés/1 Ajuntament de Barcelona, Barcelona, 1991, pp. 440-442, cat. n. 382. 
valencianas sobre las bases puestas por los grandes pintores activos ya en la última década del siglo XIV.

En contrapartida, una tabla atribuida a Marçal de Sas y a Gonçal Peris, con interrogante abierto, una cabeza de un santo monje que pudiera identificarse con la de un San Gil, fechada hacia 1410 y conservada en el Museo de Bellas Artes de Bilbao [fig. 23 ${ }^{91}$ me sugiere una modalidad pictórica más próxima a las habilidades de Guerau Gener. El juego de luces sobre el rostro del personaje es equiparable al que podemos observar sobre los rostros de los reyes magos del retablo de Santes Creus y el dibujo de la cabeza no se aparta en demasía de algunos de las caras más amables que se desvelan en este conjunto catalán. Por desgracia la obra fue mutilada y la pieza ofrece tan solo una información muy parcial sobre el retablo a que perteneciera. El fragmento es suficiente, a pesar de todo, para entender su relación más que notoria con el estilo más suave y lumínico de Guerau Gener. Bastará una confrontación de las cabezas del santo Domingo y del plausible san Gil para percatarse que se trata de obras realizadas por maestros cercanos pero distintos.

Las posibles confluencias de Marçal de Sas, en el primer caso, o de Gonçal Peris, en el segundo, obligan a advertir que la intersección confluye en la personalidad de Gonçal, Ahora bien, si Gonçal es el maestro del santo Domingo, como me parece verosímil, no pudo ser el autor del hipotético santo cenobita. Tampoco sería razonable forzar la visión de lo más característico de Marçal de Sas en la figura del ermitaño, que se representa imberbe, tonsurado y con hábito oscuro, pero del que no contemplamos atributo ninguno. $\mathrm{Su}$ imagen puede compararse y diferenciarse bien del san Gil de Miquel Alcanyís del Metropolitan Museum de Nueva York, ${ }^{92}$ y de nuevo podemos considerar también la presión de los modelos de Starnina y su entorno. Una opción plausible vuelve a ser, por tanto, Guerau, atento a las modalidades creativas de ambos valencianos, pero garante de un resultado personal específico. El modelado del rostro, retocado con notables coloretes en las mejillas, el diseño de los ojos y los labios, la nariz o las cejas, sin prescindir de la manera de resolver el cabello, tendiendo a individualizar los flecos en su caída morosa, no contradicen mucho de lo que soy capaz de advertir en el retablo de Santes Creus.

La riqueza de este período para la pintura de Valencia y Barcelona y el nutrido grupo de pintores que trabajan en ambos focos, contribuye a dar relieve al encargo recibido por Guerau del centro cisterciense, aunque fuese en segunda instancia y, probablemente, por ser en esa segunda instancia y en momento, próximo y sucesivo, a la muerte de Pere Serra, gran factótum del segundo Trecento catalán, y primer responsable del conjunto. Hay que explicar porque no fue Lluís Borrassà el elegido, a la cabeza de un taller que ya empezaba a ser dominante en el panorama barcelonés, no sin olvidar que tampoco fue Joan Mates el elegido. Sus posibilidades eran claras dado que es plausible que se hubiese formado junto a Pere Serra para encabezar un taller autónomo poco después de morir este. Es posible que Mates fuera demasiado joven todavía, y también que se deseara forzar un avance hacia las novedades que, sin duda, tomaban cuerpo desde Valencia. Se optó por un pintor que se había formado a caballo de Barcelona y Valencia, cuando las escuelas de Tarragona y Tortosa también empezaban a dar frutos interesantes. Este pintor de fortuna no excesiva, en contacto evidente con los mejores maestros valencianos, debía disfrutar hacia 1405-1406 de un reconocimiento necesario para entender que fuese él, y no otro, el llamado a substituir a Pere Serra.

El encargo de un retablo a Guerau con destinación a la catedral de Monreale abunda en la buena reputación del pintor, aunque la obra quizá no llegara a realizarse. La relación del poder real con el círculo valenciano, en tiempos del rey Martín el Humano (1396-1410), se halla seguramente entre las claves de este proceso. Santes Creus vuelve a ser reconsiderado como centro de especial interés y se decide pagar un retablo excepcional con destinación al altar mayor de la iglesia de santa María, un retablo capaz de rivalizar con el que debió poseer el monasterio de Poblet desde mediados del siglo XIV y con cualquier otro que pudiera verse en Cataluña en torno al 140o. Guerau Gener, sustituyendo al fallecido Pere Serra, iba a ofrecernos, con su fundamental intervención en el conjunto, una visión menos mística que Joan Mates, de lo que no se predica que su obra no sea sofisticada o que abandone los esquemas más atractivos del gótico internacional. El arte de Guerau controla los detalles que dotan a su pintura de una dimensión más cercana al espectador, en comparación con las desenvolturas de Mates. Su forma de idealizar no le impide avanzar en el terreno de la caricatura y lo grotesco, sin llegar a ser ordinario. Mates suaviza los contenidos algo más y los condensa por la vía ornamental, una vía que Guerau tendió a limitar y que nos aproxima a los contextos franco-flamencos y germánicos más duros, o menos decantados por lo ornamental, sin renunciar al legado de Starnina. Mates y Guerau tienen muchos puntos de contacto, pero Guerau se decanta más hacia el dibujo, frente a un Mates que convierte el color en sujeto principal. No se trata de negar en modo alguno la brillantez del colorido de Guerau, pero cuando se valora el retablo de Santes Creus debemos recordar que pesa también el acabado cromático realizado en el taller de Lluís Borrassà. El estado de conservación del retablo de la catedral y la intervención de Borrassà en el retablo cisterciense nos impiden hacer una valoración conclusiva del color en Guerau, pero la potencia de las fotos en blanco y negro del retablo de Santas Creus, del Instituto Amatller de arte hispánico (Barcelona), ponen de manifiesto la capacidad de su trabajo como gran constructor de figuras, más allá del valor cromático que las secunda.

A Guerau Gener podemos atribuirle una obra escasa pero coherente, que nos obliga a recapacitar sobre los distintos modelos que a lo largo de unos veinte años pudo tener a su alcance. Todos ellos fueron patrones con algo de extraordinario y que, con distintos objetivos y origen, nos sitúan en los lugares donde debió entrar en contacto con ellos. La obra de Guerau no quedó encerrada en las fronteras del taller, subordinada a las exigencias de los encargos y el mercado local. Con su aportación, Guerau, fue capaz de llamar la atención de centros de primer orden. Ahora bien, una vez alcanzada la fama, no pudo responder a las expectativas creadas de forma tan amplia y puntual como hubiese sido de esperar. Su muerte, presumiblemente temprana, interrumpía una carrera de indudable mérito en el 1410.

\footnotetext{
91 N. de inventario: 69/273 del Museo de Bellas Artes de Bilbao. Aparece como anónimo valenciano de la primera mitad del siglo XV y dentro de la escuela de Marçal de Sas o Sax, a quien también atiende Heriard Dubreuil, en A. GALILEA ANTON, La pintura gótica española..., pp. 104-105.

${ }_{92}^{2}$ El santo es portador de libro y báculo y formaba parte de un conjunto del que se conservan algunas escenas cristológicas (triunfo de Cristo sobre Satán y vocación de los apóstoles).
} 